\title{
Remediation of Nickel ion from wastewater by applying various techniques: a review
}

\section{sciendo}

\author{
Ameet Kumara, Aamna Baloucha, Ashfaque Ahmed Pathan ${ }^{b}$, Abdullaha, Muhammad Saqaf Jagirania, Ali \\ Muhammad Mahara, Muneeba Zubaira, Benazir Lagharia.

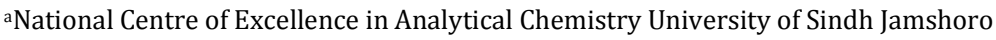 \\ bDepartment of Civil Engineering, Mehran University of Engineering and Technology, Jamshoro, Pakistan \\ *Corresponding author email: aamna balouch@yahoo.com
}

\section{DOI : 10.2478/acmy-2019-0001}

\begin{abstract}
:
The remediation of organic and inorganic pollutants from the aqueous environment has touched a certain level with the development of research Environmental pollution is increasing day by day due to industrial activities which cause a negative effect on human health and the ecosystem. Nowadays, heavy metals have a special concern due to its toxicity, persistence and bioaccumulation in nature. Toxic metals like chromium, nickel, arsenic, lead, mercury, cadmium are the main contaminants of water because they are non-biodegradable in nature. Nickel is also a toxic metal, mostly used in industries because of its anticorrosion behaviour. As a consequence nickel is present in the wastage of electroplating, tableware, metal finishing, plastics manufacturing, nickel-cadmium batteries, fertilizers and mining industries and these waste have dangerous impact on the human health and environment and causes the diseases i.e. diarrhea, anemia, hepatitis, kidney damage, gastrointestinal distress, skin dermatitis, and central nervous system dysfunction. In the present review article, several techniques are discussed for the treatment of nickel from the industrial environment. The elimination of nickel from wastewater is not important only for economic purposes but also for environmental safety.
\end{abstract}

Keywords: Nickel, Wastewater, Environmental protection, Removal techniques

\section{Introduction:}

Water pollution and its control are developing an important and global concern that need to be addressed for a healthy and fresh environment. Clean and pure water is a global problem for all living organism to sustain their healthy life [1]. Currently, almost $11 \%$ of the world population lacks access to drinking water. According to the world health organization (WHO), water shortage may affect up to 4 billion people by 2050 [2]. Water comprises of $70 \%$ of earth surface, $97 \%$ of this is very salty and the remaining $3 \%$ is stuck in underground, glaciers and in ice caps. Less than $1 \%$ of the world's water is available to us [3]. Due to enormously increase of population in the domestic, industrial and agricultural sector which consuming 8,22 and $72 \%$ of fresh water respectively and this has resulted in the generation of a large amount of wastewater which contains a large number of contaminants [1]. The important types of aquatic contaminants are dyes and toxic metal pollutants, which once enter into water than water will not be safe and pure for drinking purpose and it is very hard to treat the polluted water [4]. The contamination of toxic metals has become an important and serious problem that pollutes the environment and also the health of human beings [5]. In recent years the toxicity and effect of heavy metals on the environment have attached much considerable and extensive attention. Toxic heavy metals are considered as toxic constituents who can disturb the natural environment at low concentration and it has a tendency to enter in food chain [6]. Water pollution is produced by toxic metal ions generated from electroplating, mining, pigments, alloys, aerospace industries, rubber, plastics, and batteries [7]. Nickel is also one of the toxic heavy metal ions which are non-biodegradable and present in an aqueous environment. Nickel $\mathrm{Ni}(\mathrm{II})$ is a $24^{\text {th }}$ abundant element and has silver-white colour, hard and ductile in nature with 28 and 58.71 atomic number and atomic mass respectively [8]. Nickel has several oxidation states i.e. -1 to +4 but +2 is most common. Nickel alloys and nickel compounds are employed in various industrial and commercial applications. At low-level $\mathrm{Ni}(\mathrm{II})$ compounds are may be used for enzyme activator and contributing in metabolism reactions. The extremely use of nickel-containing compounds tends to pollute the environments [9]. Some nickel compounds i.e. carbonyl, are carcinogenic in nature and easily absorbed by skin [10]. The allowable limit of Nickel metal ions in human consumable water is $0.02 \mathrm{mg} / \mathrm{L}$ and the exceed level of $\mathrm{Ni}(\mathrm{II})$ ion concentration may cause many diseases i.e. diarrhoea, anaemia, hepatitis, kidney damage, gastrointestinal distress, skin dermatitis, and central nervous system dysfunction [11]

\subsection{Sources of Nickel (II) in Environment}

Nickel compounds are exposed by different industries i.e. electroforming, electroplating, alloys, aerospace industries, rubber, plastics, batteries and mining. They are also used for preparing jewellery, cast coins and medical purposes. They are various types of sources of nickel pollution in environment i.e. production and processing of nickel compounds and their derivatives, nickel having waste disposal and the recycling of nickel waste products. Ni(II) compounds are also obtained in soil present in both forms i.e. soluble and insoluble [12]. Ni(II) is also present in the environment and its species also depend on the source of contamination. Different industrial and anthropogenic sources are disposed of in the form of silicates, oxides, sulphides and some soluble forms. Coal and oil combustion also disposed of $\mathrm{Ni}(\mathrm{II})$ in atmospheric emission. The sediments and leaching of rocks also exposed significant nickel concentration in water and present in dissolved and un-dissolved suspended form. The divalent form of $\mathrm{Ni}(\mathrm{II})$ is high in the aquatic environment. Nickel compound depends on $\mathrm{pH}$ and inorganic or organic binding sites.

\section{2. $\quad$ Nickel Toxicity}

The toxic effects of nickel on health depend upon the route of exposure i.e. dermal, oral and inhalation. There are two types of exposure i.e. acute exposure and chronic exposure. The most toxic effect of nickel in human beings is an allergic effect which is very sensitive. Nickel is not only an allergen but also causes various diseases i.e. diarrhoea, anaemia, hepatitis, kidney damage, gastrointestinal distress and skin dermatitis. It is also a potential of hypersensitivity, immunomodulatory and immunotoxic agent in humans [13]. According to the International agency of research and cancer (IARC) and the United States Department of Health and Human Services (DHHS) [9], all nickel compounds i.e. sulphates, chlorides, carbonates and nitrates are toxic and carcinogenic in nature. The high uptake of nickel shows that it is teratogenic, toxic and carcinogenic in nature. Anke et al. studied the effect of nickel metal diet in the tissues of hens and pigsmk. They observed that with the increase of nickel concentration the other metals i.e. manganese, magnesium and zinc were decreased in different tissues of hens and pigs. If the zinc level was decreased then it could be harmful to chicken development.

Various researchers concluded that nickel causes an allergic reaction in the human body. Almost $10-20 \%$ of the population of the world exposed to nickel. Nickel may also react with skin and cause dermatitis disease. Due to these hazardous effects of nickel on human health, it is necessary to realize the actual and effective treatment technique for the remediation of additional nickel from our aqueous environment.

There were a number of review articles reported for the treatment of heavy metals by different techniques. But, none of them has given a complete explanation of one specific metal ion.

Therefore the present work purposes to critically review several removal techniques for the elimination of nickel ions from aqueous media. As a result by reading this review article, the young researchers can get complete data in which direction they have to start and further move their research.

\section{Treatment of Nickel from Industrial wastewater}

Researchers used several types of treatment techniques for the remediation of nickel from different types of industrial wastewater i.e. chemical precipitation, ion-exchange, adsorption (activated carbon, bio-sorbents, agricultural waste adsorbents, alumina, and carbon nanotubes), electrochemical methods (electro-coagulation, electro-floatation and electro-deposition) and current methods (membrane filtration and nanotechnology) [14-18]. 


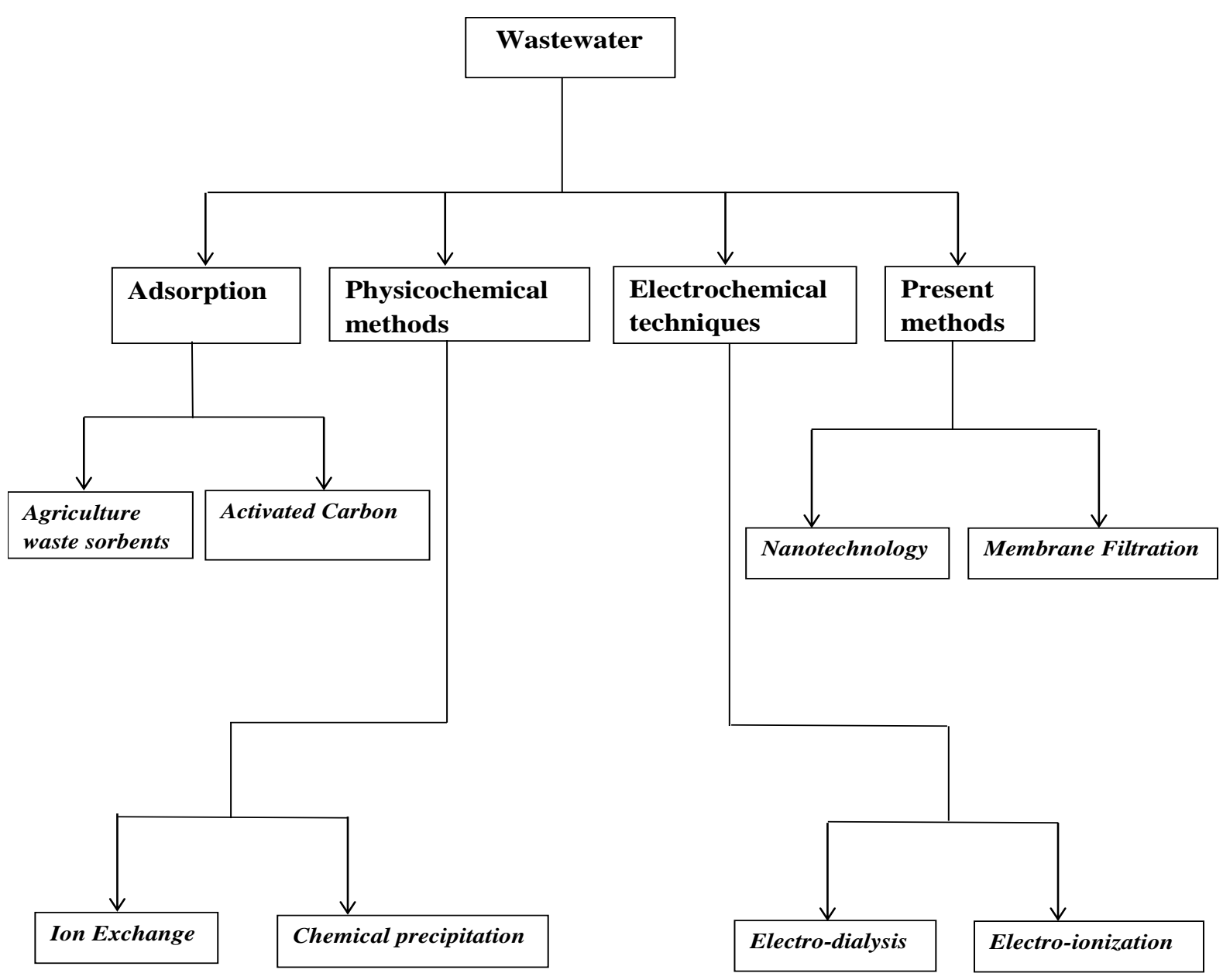

Fig.1:

techniques used for the treatment of Nickel (II)

\subsection{Chemical precipitation}

Chemical precipitation is a simple and easiest method which is widely employed for the removal of toxic metals from inorganic effluent [19]. In chemical precipitation, precipitating agents react with toxic metal ions and formed insoluble solid particles [14]. This method requires a lot of chemicals for the reduction of toxic metal ions up to an acceptable limit of discharge but sometimes it also fails to reach up to that point. These chemicals also become a source of further environmental pollution [20,21]. Chemical precipitation of nickel obtained by raising its $\mathrm{pH}$ of the solution and turned it into basic condition, while the metal is changed into insoluble nickel hydroxide, $\mathrm{Ni}(\mathrm{OH})_{2}$. This method requires a lot of chemicals for the reduction of toxic metal ions up to an acceptable limit of discharge but sometimes it also fails to reach up to that point. These chemicals also become a source of further environmental pollution [21].

Giannopoulou et al. have exposed the probability of separating of Nickel ( $\mathrm{Ni}$ ) and Copper ( $\mathrm{Cu}$ ) from low pH solutions, by the electrodepositing of $\mathrm{Cu}$ earlier to $\mathrm{Ni}$ with high removal per cent of $\mathrm{Ni}$ as $99.56-99.76 \%$ respectively [22]. The precipitation was obtained at the temperature $60-95^{\circ} \mathrm{C}$, where $\mathrm{Ni}(\mathrm{OH})_{2} \mathrm{could}$ be attained by super-saturation precipitation [23].

Escudero et al. investigated the elimination of $\mathrm{Ni}(\mathrm{II})$ by chemical precipitation [24]. In this study, the $\mathrm{Ni}(\mathrm{II})$ shifted in one crystalline form $\mathrm{Ni}(\mathrm{OH})_{2}$. This type of transformation depends on the $\mathrm{pH}$ of the solution. The precipitation of $\mathrm{Ni}(\mathrm{OH})_{2}$ starts after the $\mathrm{pH} 9.0$. The physic-chemical properties were also studied such as $\mathrm{Ni}(\mathrm{II})$ activity, ionic strength reduced above the $\mathrm{pH} 7.6$ due to the proceeding of precipitation. Tanong et al. studied the separation of nickel and manganese by the addition of sodium carbonate, which is totally precipitated at $\mathrm{pH} 9.0$. This process is not used for the treatment of nickel at little concentration [25].

Subbaiah et al. investigated the probability of attaining Nickel hydroxide $\mathrm{Ni}(\mathrm{OH})_{2}$ in the existence of nitrate ions by electrochemical precipitation [26]. By using an electrolytic as a cell, in which titanium is used as a cathode and stainless steel as an anode, the $\mathrm{Ni}(\mathrm{OH})_{2}$ could be found by using $\mathrm{NiSO}_{4}$ and nitrate ions present in the solution. The results obtained the effectiveness of current increases with the concentration of nickel and decreases when the temperature and current density are increases. Figure 2: shows the diagram of the Chemical precipitation method for the remediation of Ni(II) ions. 


\section{Chemical Precipitation}
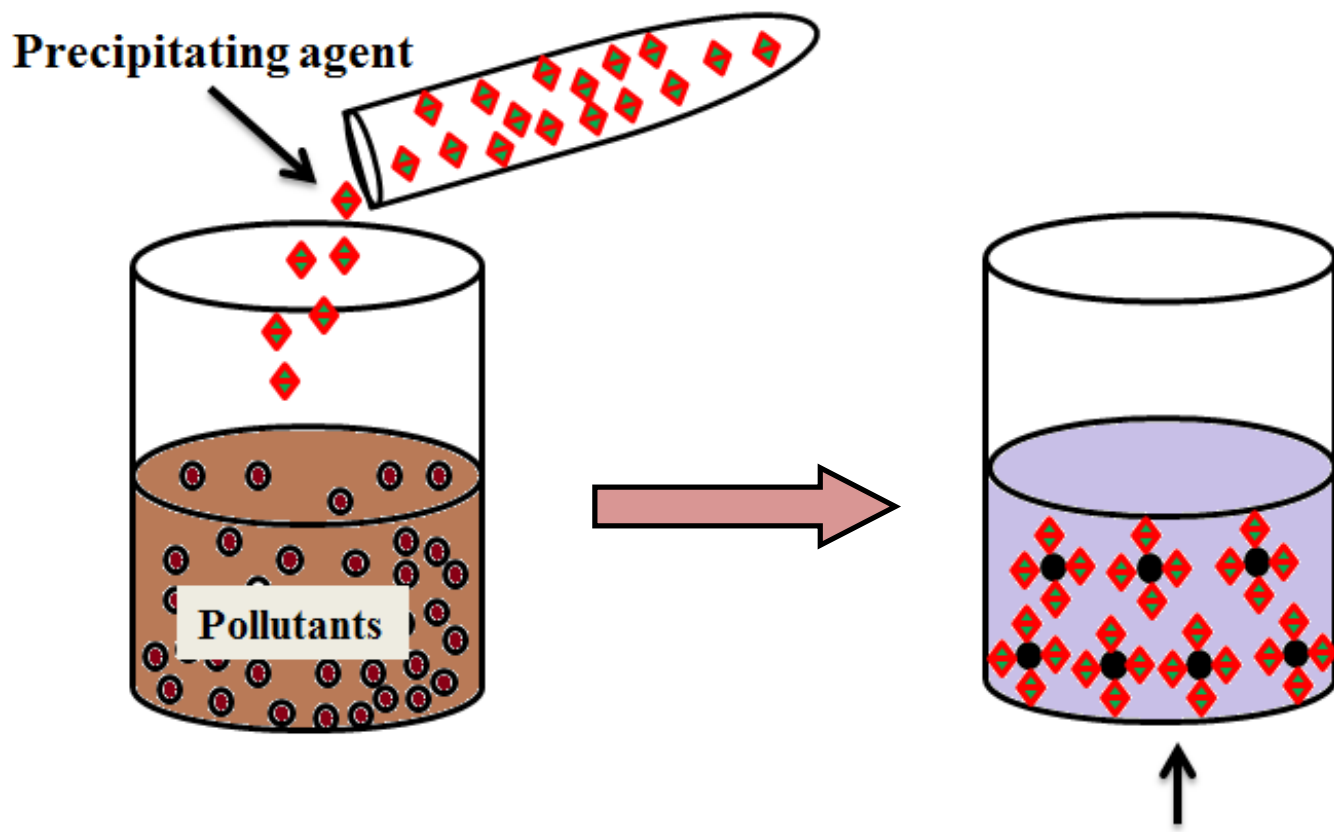

Precipitates form and settled down

Figure 2: Diagram of Chemical precipitation method for the remediation of $\mathrm{Ni}(\mathrm{II})$ from aqueous solution. Advantages

$>$ Chemical precipitation method used for the water softening and stabilization.

This method is widely used for metal industries to remove the soluble heavy metal ions. Limitations

$>$ This method requires a large number of chemicals. So the cost of precipitation becomes high.

$>$ This method is not a convenient method for domestic wastewater because it contains low metal concentration.

\subsection{Ion Exchange}

Ion exchange (IE) is a technique in which one or more undesirable ions are removed from water by exchange with other desirable or less desirable ions. By using this process, the unwanted ions are exchanged by another ion which is less dangerous to the environment [27]. Ion Exchange is a treatment technique which depends on the reversible interchange of ions between solid and liquid phases. Ion exchange technique is broadly and widely used for the treatment of toxic heavy metals from industrial wastewater due to their several advantages i.e. high removal efficiency, high adsorption capacity and rapid kinetics. The toxic heavy metals physically adsorbed on ion exchange resins and the complex is formed between the functional group and targeted ion. At the last, the hydration occurs at the surface of the solution and pores of the resin $[28,29]$. The ion exchange process is affected by several factors i.e. temperature, $\mathrm{pH}$, contact time and initial concentration of sorbent [30]. For the treatment of nickel, several ions exchange resins and zeolites were shown to be effective [31]. Kumar et al. studied the treatment of toxic nickel from industrial wastewater by using a Ceralite IR 120 cationic exchange resin (CXR) as an adsorbent material under different conditions [32]. Batch adsorption studies revealed that by increasing the concentration of $\mathrm{Ni}^{2+}$ the adsorption is decreased at $\mathrm{pH}$ 5.0. The Langmuir adsorption capacity was obtained $28.57 \mathrm{mg} / \mathrm{g}$. Dave et al. studied on the remediation of nickel from electroplating wastewater by using basic anion exchange resins [33]. In this work, the effect of initial concentration of an ion, dose study and $\mathrm{pH}$ on exchange capacity of resin were carried out. The adsorption method was $\mathrm{pH}$ sensitive and maximum adsorption was obtained at $\mathrm{pH}$ 4.0-6.0, the initial concentration of $\mathrm{Ni}(\mathrm{II}) \mathrm{was}$ 5-30mg/L and the adsorbent dose was $25-700 \mathrm{mg} / \mathrm{L}$. It was found that the adsorption of nickel by using an ion exchange resin was reversible in nature and it has the potential for the treatment of nickel from wastewater. Zewail et al. investigated the removal of Ni(II) by using strong cationic exchange resins (AMBERJET $1200 \mathrm{Na}$ ) from wastewater [34]. They studied the effect of different parameters i.e. contact time, initial concentration and superficial air velocity. At under optimum conditions, they found the maximum removal per cent of $\mathrm{Ni}(\mathrm{II})$ was $98 \%$. The data of $\mathrm{Ni}(\mathrm{II})$ was well fitted towards the pseudo-second-order model. Figure 3: shows the diagram of the ion exchange technique for the remediation of $\mathrm{Ni}(\mathrm{II})$ ions. 
Ion exchange Technique

Nickel Water

Ion Exchange Technique

\section{Treated Water}

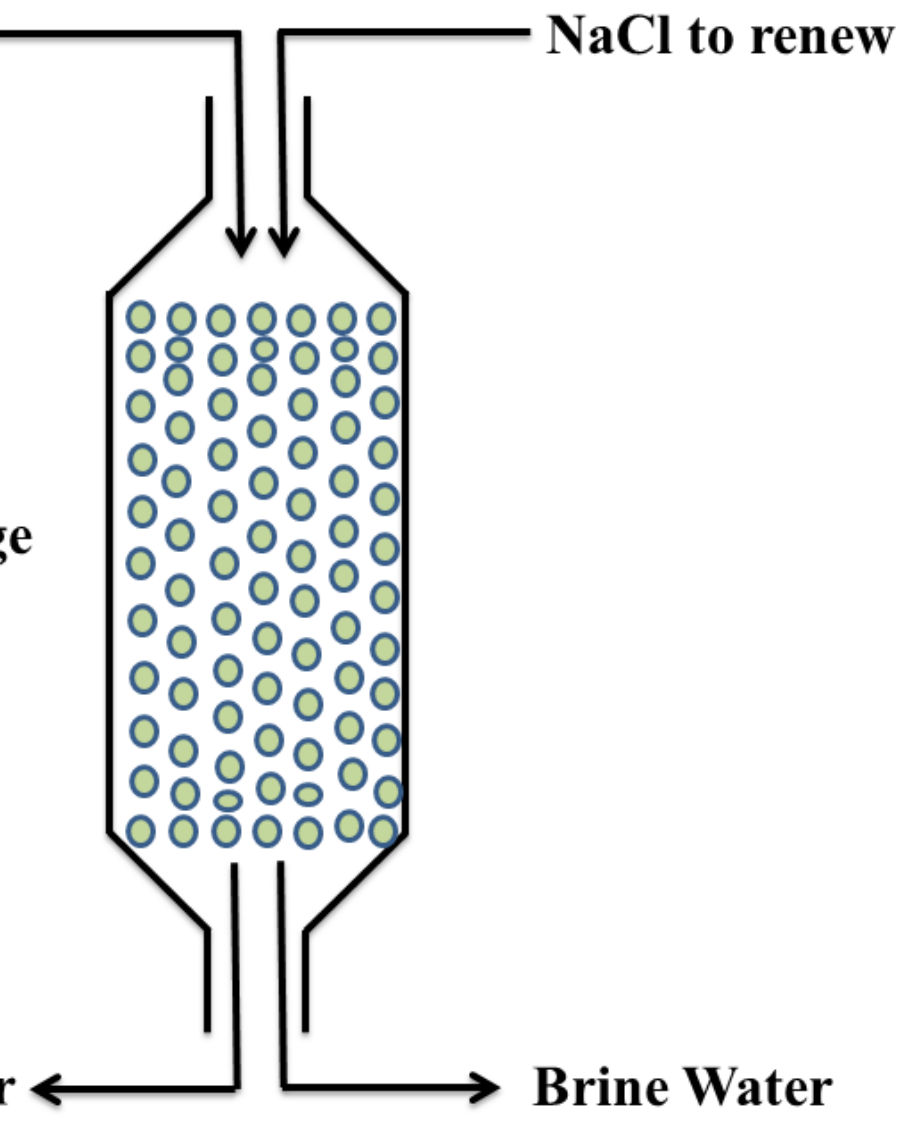

Figure 3: Diagram of Ion Exchange technique for the remediation of Ni(II) from aqueous solution. Advantages

$>\quad$ It is a very effective and efficient technique used for water treatment. Limitations

$>$ The wastewater which is produced by ion exchange technique is also used for water treatment.

$>\quad$ The acidity of water can be increased because of the sodium ions into softened water, which make water not for safely use.

$>\quad$ In Ion exchange resins, precipitates i.e. iron oxide or calcium sulphates are formed which can foul the exchange resins. $\hat{\jmath}$

$>\quad$ Ion exchange resins are highly expensive than adsorbents.

\subsection{Ion Flotation}

Ion flotation is a promising process for the separation of toxic metals from industrial wastewater. It is a separation and elimination process for the treatment of surface-inactive ions from the aqueous media by the addition of a surfactant which has an opposite charge to the removal metal ion [15, 35]. When the surfactants are added into the industrial effluent, the metal ion is transferring into the hydrophobic phase. These metal ions in the hydrophobic phase react with air bubbles to form flocks and elimination of flocks takes place respectively. Ion flotation technique was employed for the remediation of toxic heavy metal ions from an aqueous solution which has little concentration.

Hoseinian et al. used ion flotation technique for the remediation of Ni(II) ions from synthetic wastewater [36]. The effect of several parameters i.e. pH, ionic strength, surfactant concentration and activity coefficient were checked during the removal of nickel ions. It was observed that the removal efficiency of nickel increased by increasing $\mathrm{pH}$ and obtained $100 \%$ removal at $\mathrm{pH}$ 9.7. The kinetic studies also revealed that the removal of nickel was affected by $\mathrm{pH}$ Doyle et al. investigated for the separation of nickel,sodiumdodecylsulfate was used as surfactant and triethylenetetramine (Trien), was used as a neutral chelating agent. During the ion flotation with sodiumdodecylsulfate, Trien was shown the increase adsorption per cent of Ni( $10 \%)$ and Cu( $20 \%)[37]$. Another study was done by Liu et al. in which dodecyldiethylenetriamine (Dien) was used as non-ionic surfactant [38]. This investigation shows the ion flotation behaviour of $\mathrm{Ni}^{2+}, \mathrm{Cu}^{2+}$ and $\mathrm{Co}^{2+}$ by using Ddien. When the $\mathrm{pH}$ of the solution is at 9.0 the $\mathrm{Ni}^{2+}$ and $\mathrm{Co}^{2+}$ ions separated from the solution than $\mathrm{Cu}^{2+}$ ions. The initial concentration of $\mathrm{Ni}(\mathrm{II})$ was decreased from the initial value from $0.15 \mathrm{mM}-0.01 \mathrm{mM}$ ( $\sim 93 \%$ reduction). Turtureanu et.al studied for the treatment of $\mathrm{Ni}(\mathrm{II})$ by ion flotation process [39]. In this technique, flotation was combined with cationic collectors for the treatment of nickel. The optimum parameters i.e. $\mathrm{pH}$, molar ratio, temperature, air flow rate flotation time were also studied. At pH 10 the removal percent was obtained up to $98 \%$. In another study, Ethylhexadecyldimethylammonium bromide (EHDABr) and sodium dodecyl sulfate (SDS) was used as a collector for the elimination of $\mathrm{Ni}^{2+}$ and $\mathrm{Zn}^{2+}$ ions. The effects exposed that the removal of Ni(II) from wastewater was 88.5\%-92.8\% [40]. Figure 4: shows the diagram of ion flotation technique for the remediation of $\mathrm{Ni}(\mathrm{II})$ ions. 


\section{Ion Flotation Technique}

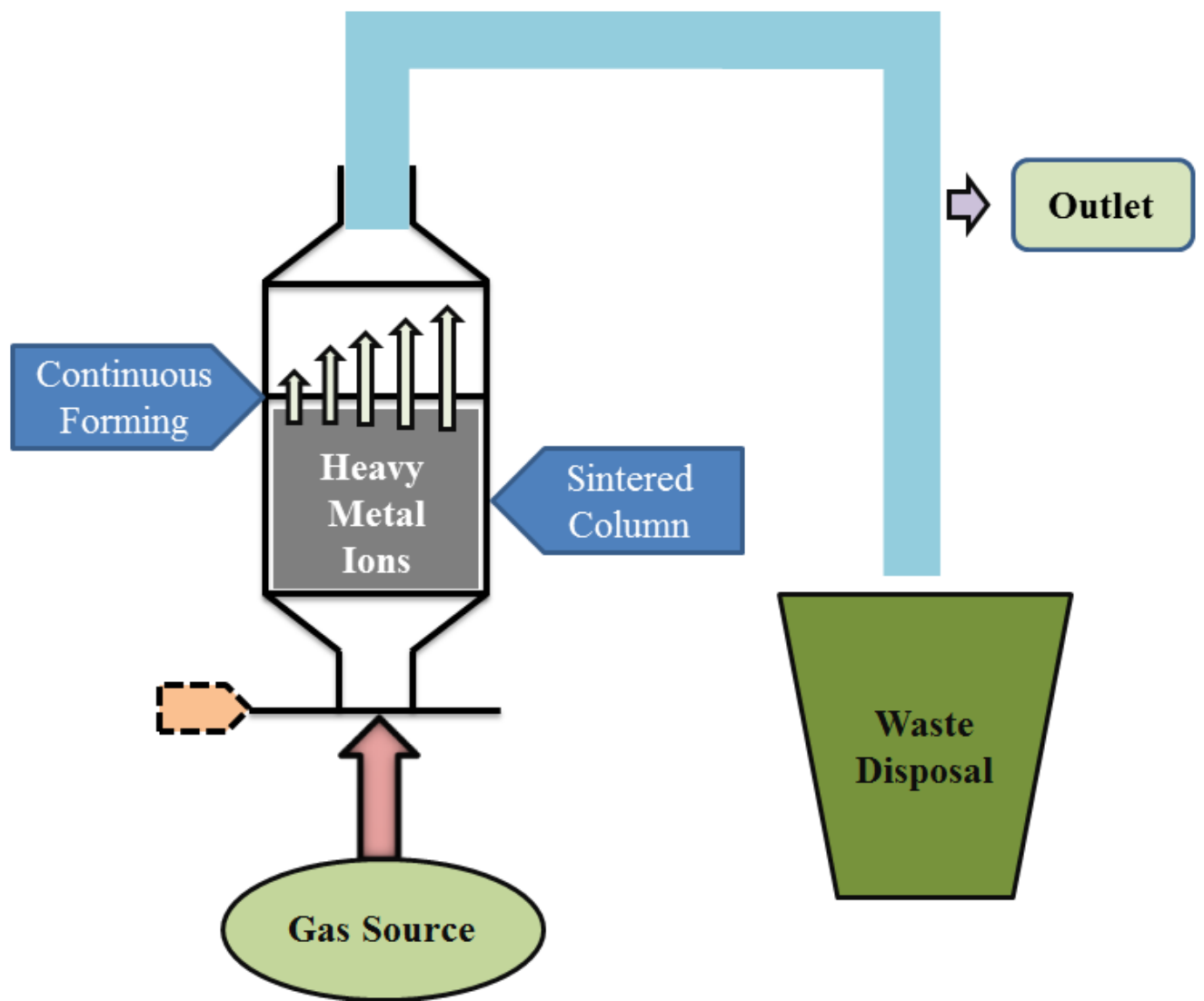

Figure 4: Diagram of Ion Flotation Technique for the remediation of Ni(II) from aqueous solution. Advantages

This technique can eliminate the low-density particles which require large time for settling.

$>$ It can provide high flotation concentration.

$>$ It has the ability to handle variable solids and can adjust the flow of air. Limitations

$>$ It is highly expensive and energy consuming technique.

\subsection{Membrane Filtration}

Membrane filtration is pressure driven, worldwide and separation technique for the removal of inorganic compounds from the aqueous environment with high efficiency, space saving, and easy operation [41]. Membrane filtration separates the particles on the basis of pH, the concentration of the solution, size and applied pressure. The membrane is prepared from a porous material which is used for the treatment of inorganic metals from the waste of industries [42]. To find jthe environment-friendly separation process, Membrane filtration like reverse osmosis (R.0), ultrafiltration (UF), and nano-filtration (N.F) are employed for the treatment of nickel from industrial wastewater.

\subsubsection{Reverse Osmosis (R.O)}

The principle on reverse osmosis works i.e. charge exclusion and size exclusion. Reverse osmosis R.O is a general wastewater treatment process in environmental and chemical engineering [14]. R.O is a membrane filtration process where water can easily pass through a membrane however cationic compounds are retained [28]. The pore size of the R.O membrane is $0.1 \mathrm{~nm}$. R.O can be used for all solutions which have less quantity of metal dissolved in the millimolar or micromolar range. Few studies reported for the treatment of $\mathrm{Ni}(\mathrm{II})$, reverse osmosis technique has been revealed to work efficiently and effectively. Mohsen-Nia et al. prepared a tin composite film which was the type of reverse osmosis membrane for the treatment of Ni(II) and Cu(II) [43]. The removal efficiency depends on general parameters i.e. pressure, temperature and ionic concentration. The removal of ions depends upon the osmosis pressure. The treatment of $\mathrm{Cu}(\mathrm{II})$ and $\mathrm{Ni}(\mathrm{II})$ from aqueous solution by R.O process and the removal efficiency increased by adding chelating agent i.e. $\mathrm{Na}_{2}$ EDTA. The removal efficiency increased up to $99.5 \%$. Ipek et al. carried out the research for the treatment of Ni(II) and Zn(II) from aqueous environment by using reverse osmosis R.O at different EDTA concentrations, pH and conductivity [44]. In this study, the remediation in the pre-treatment units (PU) with filtration (F) and granular activated carbon (GAC) was measured at similar conditions. By using P.U the removal per cent of $\mathrm{Ni}(\mathrm{II})$ and $\mathrm{Zn}(\mathrm{II}) \mathrm{was} 23$ to $25 \%$ and 25 to $45 \%$ while using P.U with R.0 the removal per cent was increased up to $99.2 \%$ of Ni(II) and $98.8 \%$ of $\mathrm{Zn}$ (II).

\subsubsection{Ultrafiltration (U.F)}

Ultrafiltration is a removal process which needs less amount of energy for the treatment of industrial effluent. In ultrafiltration (U.F), membrane permits the flow of water with low molecular weight solutes, whereas the larger molecules and heavy metal ions which has a larger pore size than the membrane. Sometimes the pore size of U.F membrane (3-20nm) is larger than dissolved metal ions [14]. For the treatment of nickel, Landaburu-Aguirre et al. prepared micellar enhanced ultrafiltration, Borbély G et al. prepared complexation ultrafiltration and Kryvoruchko et al. prepared chelating enhanced ultrafiltration. In the study of micellar enhanced ultrafiltration (MEUF) was used for the removal of toxic metals simultaneously from the effluent of fertilizer company [45]. The parameters were optimized i.e. $\mathrm{pH}$, temperature and SDS feed concentration. At lower $\mathrm{pH}$, the removal efficiency of copper and cadmium was more efficient. Furthermore, the removal coefficient values for nickel and zinc shows that copper was trapped in small quantity and the MEUF removal efficiency was as follows: $\mathrm{Zn}=\mathrm{Ni}>\mathrm{Cd}>\mathrm{Cu}$. In complexation ultrafiltration technique, $\mathrm{Ni}(\mathrm{II})$ and $\mathrm{Zn}$ (II) etc. are eliminated from water before recycling or discharge into surface water [46]. During optimization pH and a metal ratio have been examined. The efficient and effective composition for heavy metals was PES-10 membrane, PAA complexation agent and $\mathrm{pH}>8$. Kryvoruchko et al.et al. prepared chelating enhanced ultrafiltration for the treatment of contaminated water which is polluted by $\mathrm{Co}(\mathrm{II})$ and $\mathrm{Ni}(\mathrm{II})$ [47]. The maximum removal efficiency by using UPM-20 membrane of $\mathrm{Ni}(\mathrm{II})$ and $\mathrm{Co}(\mathrm{II})$ was $99.9 \%$ and $95.0 \%$ and the pressure range was $200-500 \mathrm{kpa}$. In this study, ethylene imine was used as a chelating agent.

\subsubsection{Nanofiltration (N.F)}

Nanofiltration is relatively currently membrane filtration technique used often with low dissolved solids water i.e. groundwater and surface water with the purpose of softening and elimination of disinfection by-product precursors i.e. synthetic organic matter and natural organic matter. Nanofiltration is an excellent process. The mechanism of separation includes both electrical effects and pore size [28]. Nanofiltration membranes are also known as "low- 
pressure reverse osmosis membrane". Murthy et al. prepared thin-film composite polyamide nanofiltration membrane for the removal of nickel metal ions from water stream [48]. In this study, different parameters were optimized i.e. applied pressure, feed concentration, $\mathrm{pH}$ and flow rate. It was found that the elimination of nickel metal ions increases with the increase of feed pressure and become reduced with the increase of feed concentration at the same flow rate. The maximum removal of nickel ions from water is up to $98 \%$ for $5 \mathrm{ppm}$ feed concentration and $92 \%$ for $250 \mathrm{ppm}$ feed concentration. Murthy et al also prepared NF300 nanofiltration membrane for the elimination of Ni(II) from the electroplating industry [49]. The electroplating wastewater contains several toxic metal ions i.e. Nickel, Magnesium, Sodium and Zinc. The NF300 nanofiltration membrane removed toxic nickel metal ion up to $97.9 \%$ for $5 \mathrm{ppm}$ initial concentration and $96.8 \%$ for $10 \mathrm{ppm}$ initial concentration. Figure 5: shows the diagram of different membranes used in membrane filtration techniques and Table 1: shows the removal efficiency of various membrane filtration techniques for the remediation of Ni(II) ions.

\section{Membrane Filtration Technique.}

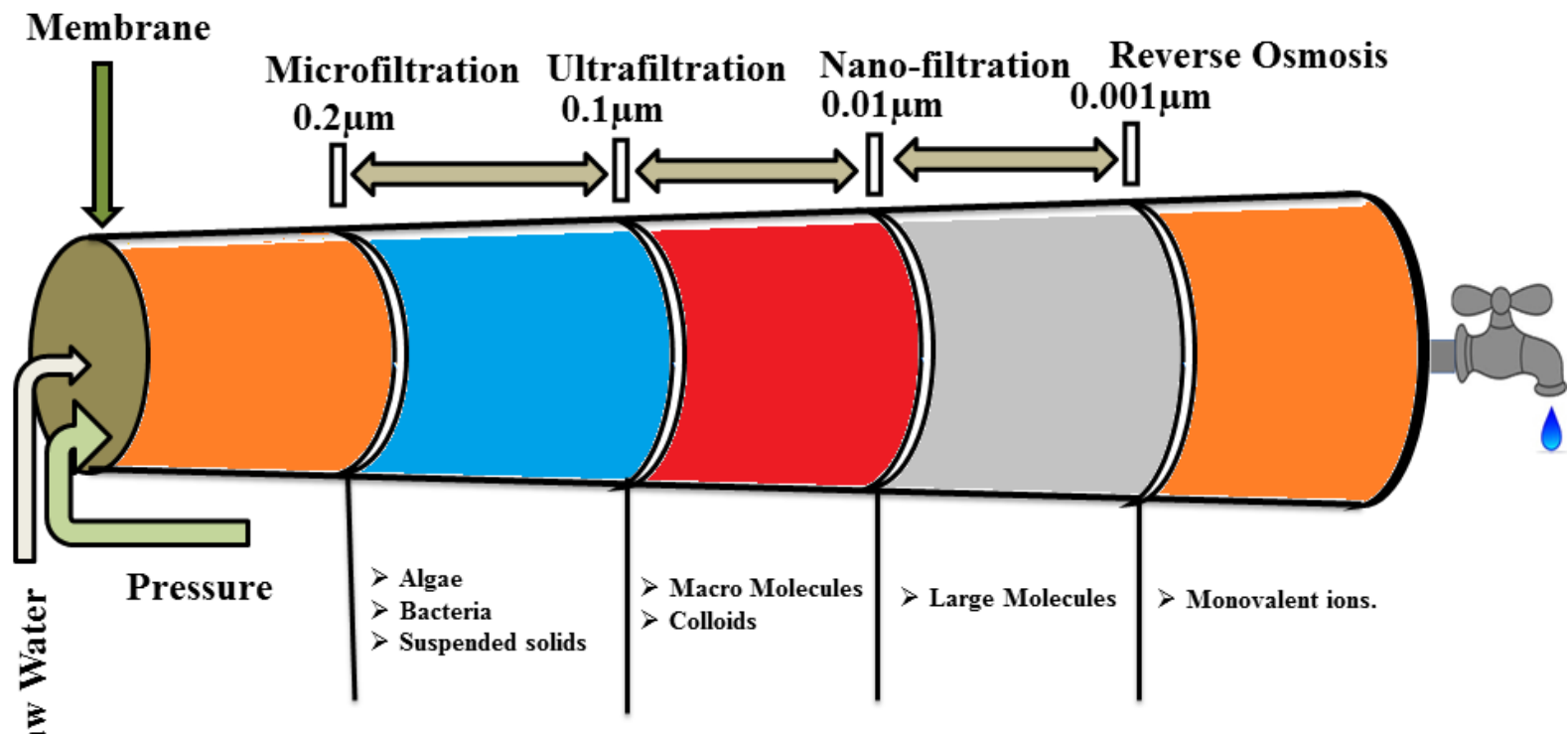

Figure 5: Diagram of Membrane Filtration Technique for the remediation of Ni(II) metal ions.

\begin{tabular}{llllll}
\hline S.no. & Technique & Initial Conc. $\mathbf{~ m g / L}$ & $\begin{array}{l}\text { Removal } \\
\text { efficiency } \%\end{array}$ & pH & References \\
\hline 1. & Micellar-enhanced & 10 & $88-99.2$ & $5.3-6.3$ & {$[50]$} \\
& UF & $0.95-1.76$ & $73.6-85.1$ & $3.5-5$ & {$[45]$} \\
\hline 2. & Complexation - UF & 58.71 & $31.5-98.2$ & $7-9$ & {$[46]$} \\
& & $98-99$ & $3-9$ & {$[51]$} \\
\hline 3. & 50 & 25 & $24.1-94.2$ & NA & {$[47]$} \\
\hline 4. & 3.36 & 96.8 & $3.6-7$ & {$[52]$} \\
& Chelation - UF & $44-169$ & 99.7 & $6.5-7.5$ & {$[44]$} \\
\hline 5. & 5.87 & $92-93$ & $4-8$ & {$[53]$} \\
& RO & $5-250$ & $92-98$ & $2-8$ & {$[48]$} \\
& $5-10$ & $96.87-97.96$ & $2-10$ & {$[49]$} \\
\hline
\end{tabular}

Table.1 List of different membrane filtration used for the remediation of Ni(II) metal ions.

Advantages:

$>$ Membrane filtration is a separation and purification technique used for the separation of a wide variety of constituents employed in the industries.

$>\quad$ This technique can be work effectively at low temperature.

$>$ This technique is very simple, efficient and requires a low amount of energy.

Limitations

$>$ This technique is highly expensive

As the concentration of metal increases, the elimination of membrane is decreased.

$>$ If the membrane manufacturing process is not controlled precisely than the wide range of pores will form in the membrane and it gives poor separation performance. 
Adsorption is based on mass transfer method in which compound is shifted and collects at interference between two phases i.e. liquid phase and solid phase. The liquid substance which joints on the surface of solid via physical or chemical interaction called adsorbate and the solid at which adsorption takes place is called adsorbent. Adsorption is a highly efficient technique for the treatment of water and it is low cost, easy operation and simple to design [41].

\section{Adsorbents for the treatment of Nickel metal ions:}

\subsubsection{Activated Carbon (AC)}

Activated carbon is the simplest and crude form of graphite, which has a highly porous and rough structure with a variation of pore size. Activated carbons are the attractive and interesting adsorbents used for the remediation of inorganic metal pollutants due to their maximum adsorption capacity, larger surface area, reusability and special surface reactivity [54]. There are four different types of activated carbon i.e. Granular Activated Carbon (GAC), Powder Activated Carbon (PAC), Activated Carbon Fibrous (ACF), Activated Carbon Cloth (ACC) depends on their shape and size.

Commercial Activated Carbon is used as a good sorbent for the remediation of toxic metals from industrial effluent but due to high cost, its usage is limited [55]. Furthermore, the CACs after one used they become useless and now it no more capability to absorbing the further amount of effluent. Once CACs are used, then it can be renewed by such a method as chemical, thermal, oxidation. But again it has high regeneration cost and its adsorption capacity also decreased [56]. To get control over these problems, the activated carbon and its usage from its derivatives attained great attention for the removal process of metals and it less expensive [57].

Ewecharoen et al. compared the adsorption capacity of grafted activated carbon and un-grafted activated carbon [58]. The adsorption capacity of grafted activated carbon and un-grafted activated carbon was $(55.7 \mathrm{mg} / \mathrm{g})$ and $(44.1 \mathrm{mg} / \mathrm{g})$ at $\mathrm{pH}$ 8. The maximum adsorbent dose was $0.1 \mathrm{~g} / 10 \mathrm{~mL}$ with the contact time of $120 \mathrm{~min}$.In another study, the activated carbon is used as a consequent of many agricultural waste products but among all, the Seed Carbon is a waste material which was formed by Citrus limettioides peel, had maximum removal capacity of Ni(II) metal ions around $35.54 \mathrm{mg} / \mathrm{g}$ at pH 6.5 [59]. This process was spontaneous in nature and fitted with the Langmuir adsorption model. Pehlivanet al. studied the adsorption capacity Ni(II) ions on activated carbon and lignite which was derived from black and brown coal [57]. In this study, the lignite has maximum removal capacity around $13.0 \mathrm{mg} / \mathrm{g}$ as compared to beysehir lignite and activated carbon which has $12.0 \mathrm{mg} / \mathrm{g}$ and $5.4 \mathrm{mg} / \mathrm{g}$. This process is exothermic in nature and obeyed Langmuir adsorption model. Keranen et al. investigated the treatment of Nickel and Vanadium toxic metals from industrial effluent [60]. In this study activated carbon was used as adsorbent and removal capacity of $4.36 \mathrm{mg} / \mathrm{g}$ at $\mathrm{pH} 5.5$ with the dose of $5.0 \mathrm{~g} / \mathrm{L}$. Kadirvelu et al. synthesized coir-pith carbon for the treatment of Ni(II) from industrial effluent [61]. It has a maximum adsorption capacity up to $62.5 \mathrm{mg} / \mathrm{g}$ in $120 \mathrm{~min}$ contact time at $\mathrm{pH}$ 6.0. This process follows the Langmuir adsorption model. Choksi et al. studied the remediation of divalent nickel by using wood charcoal and activated charcoal from the industrial wastewater [62]. The adsorption capacity of $\mathrm{Ni}(\mathrm{II})$ by using wood charcoal and activated charcoal was $96.0 \mathrm{mg} / \mathrm{g}$ and $99.0 \mathrm{mg} / \mathrm{g}$ obtained at the $\mathrm{pH} 7.5$. Wang et al. studied on walnut shell carbon for the treatment of $\mathrm{Ni}(\mathrm{II})$ ions from the aqueous environment [63]. The maximum adsorption was found $15.34 \mathrm{mg} / \mathrm{g}$ at the temperature $303 \mathrm{~K}$. The sorption data were well fitted towards the Langmuir isotherm model and pseudo-second-order kinetics. The negative values of $\Delta \mathrm{C}$ suggest that reaction is spontaneous in nature. Betancur et al. investigated Kraft lignin for the treatment of trace $\mathrm{Ni}(\mathrm{II})$ ions from industrial wastewater [64]. The adsorption efficiency of nickel by using Kraft lignin was obtained $90 \%$ at the $\mathrm{pH}$ 5.8. The data was well fitted towards Freundlich isotherm and obeyed pseudo-second-order kinetics. Table 2: shows the adsorption capacities of several adsorbents for the remediation of $\mathrm{Ni}(\mathrm{II})$ ions.

\begin{tabular}{llllll}
\hline S.no & Adsorbents & $\begin{array}{l}\text { Adsorption } \\
\text { Capacity (mg/g) }\end{array}$ & $\begin{array}{l}\text { Thermodynamic } \\
\text { Study }\end{array}$ & pH & References \\
\hline 1. & Wood Charcoal & 96.0 & Endothermic & 7.5 & {$[62]$} \\
\hline 2. & Activated charcoal & 99.0 & Endothermic & 7.5 & {$[62]$} \\
\hline 3. & $\begin{array}{l}\text { Walnut Shell } \\
\text { Carbon }\end{array}$ & 15.34 & Endothermic & 6.0 & {$[63]$} \\
\hline 4. & $\begin{array}{l}\text { Citrus limettioides } \\
\text { seed carbon (CLSC) }\end{array}$ & 35.54 & $\begin{array}{l}\text { Spontaneous and } \\
\text { Exothermic }\end{array}$ & 6.5 & {$[59]$} \\
\hline 5. & 13.0 & Exothermic & $4.5-5.5$ & {$[57]$} \\
\hline 6. & Lignite & $90 \%$ & -- & 5.8 & {$[64]$} \\
\hline 7. & Kraft lignin & Exothermic & $\begin{array}{l}4.5 \\
\text { e5.5 }\end{array}$ & {$[57]$} \\
\hline
\end{tabular}

Table 2: The maximum adsorption efficiency of different activated carbons is shown for the removal of Ni(II) ions.

\subsubsection{Non-Conventional adsorbents}

Activated carbon has been widely used for the treatment of toxic metals from wastewater and controls pollution throughout the world. While the regeneration cost of activated carbon is very high and limits its application on a large scale for the treatment of aquatic contaminants, and it encouraged the researchers to found the low-cost adsorbents. The agro-wastes materials used as adsorbents are receiving a wide consideration due to their low cost and plentiful accessibility. The main components of agricultural waste products are cellulose and lignin which contains various functional groups i.e. alcohols, ketones, carboxylic acid and ether bonding. These groups possess the capability to strongly joints with heavy metals and utilized the pair of an electron to form complexes [65].

\subsubsection{Agricultural wastes materials}

Agricultural solid waste is used as adsorbents and they existing in larger quantities because of their physicochemical interactions [66].

Rice husk is known as an agricultural waste product and rice industries by-product which comprises of floristic fibre, proteins and several functional groups i.e. hydroxyl, carboxyl and amidogen it makes adsorption more feasible. In addition, the large amount of rice husk acquired from agriculture as a by-product. Zafar et al. improved the rice bran by using several chemicals and used it for the removal of Ni(II) ions [66]. Researchers compared the adsorption capacity of rice bran treated with sodium hydroxide and hydrochloric acid which were $(153.6 \mathrm{mg} / \mathrm{g}$ and $149.4 \mathrm{mg} / \mathrm{g}$ ). The adsorption capacity of calcium treated rice bran and sulphuric acid rice bran were $(144.0 \mathrm{mg} / \mathrm{g}$ and $140.0 \mathrm{mg} / \mathrm{g})$ at $\mathrm{pH} 6.0$. This process followed the pseudo-second-order model and Langmuir adsorption model.

Coir pith is a waste material produced by the coir industry, where the coconut is formed on a large amount. Coir pith is fibre which removed from coconut husk. When the fibre was separating from the husk, a large quantity of pith was collected during the process. The coir pith has a large amount of cellulose $(44 \%)$ and lignin $(36 \%)$. So it can be utilized as an adsorbent for the remediation of nickel and reduce the toxic heavy metal ions from industrial wastewater Ewecharoen et al. used the coir pith for the treatment of $\mathrm{Ni}(\mathrm{II})$ from electroplating effluent [67]. At optimum conditions, the maximum removal capacity of nickel by using coir pith and modified coir pith was 9.5 and $38.9 \mathrm{mg} / \mathrm{g}$ at pH $4-7$, where the equilibrium time was $10 \mathrm{minn}$ at temperature $30^{\circ} \mathrm{C}$.

Several solid waste adsorbents are readily available from cheap sources i.e. coconut nutshell (CNS), Citrus Limettioides peel carbon (CLPC), Tea factory waste, pine cone and modified pine cone, sawdust, tea waste leaves are used successfully for the remediation of Ni(II) ions from aqueous solution. Thevannan et al. used barley straw for the remediation of $\mathrm{Ni}(\mathrm{II})$ metal ions from industrial wastewater which generates from nickel plating industry [68] The adsorbent was very sensitive to $\mathrm{pH}$ and obtained maximum adsorption capacity at $\mathrm{pH} 4.8$ was $35.8 \mathrm{mg} / \mathrm{g}$. The nickel bio-adsorption was well fitted to the Langmuir isotherm model and pseudo-second-order kinetics. Zafar et al. studied chemically modified bio-adsorbents i.e. rice bran (RB) and Hydrochloric acid treated rice bran (HARB) for the treatment of $\mathrm{Ni}(\mathrm{II})$ metal ions from aqueous solution [69]. The adsorption capacity of (RB) was 102 mg/g while the adsorption capacity of (HARB) was $149.4 \mathrm{mg} / \mathrm{g}$. The data followed pseudo second order kinetics and Langmuir isotherm. Bhatnagar er al. investigated Punica granatum peel waste for the bio-sorption of nickel from the aqueous environment [65]. Batch adsorption studies were done to obtain maximum adsorption capacity and several parameters were optimized. The adsorption capacity of nickel by using punica granatum peel was $52 \mathrm{mg} / \mathrm{g}$. The reaction was endothermic in nature and followed the Langmuir adsorption model. Sudha et al. used Citrus Limettioides peel for the remediation of Ni(II) from industrial wastewater [59]. Adsorption studies were performed by varying several parameters i.e. pH, temperature, contact time and adsorbent dose. The maximum adsorption capacity by using Citrus Limettioides peel was observed $38.46 \mathrm{mg} / \mathrm{g}$. The adsorption data followed the Langmuir isotherm model and pseudo-second-order kinetics. Kumar et al. studied the adsorption behaviour of nickel ions on Cashew nut shell by varying different parameters i.e. $\mathrm{pH}$, temperature, adsorbent dose, contact time and initial concentration of nickel ions [70]. The maximum adsorption capacity by using cashew nut shell was 
obtained $20 \mathrm{mg} / \mathrm{g}$ and followed the Langmuir isotherm model. The kinetic studies show that the adsorption behaviour of nickel ions which followed pseudo second order kinetics. The values of $\Delta \mathrm{G}$ and $\Delta \mathrm{H}$ suggest that reaction is spontaneous and exothermic in nature. Malkoc et al used Waste acorn of Quercus ithaburensis (WAQI) as a adsorbent for the adsorption of $\mathrm{Ni}(\mathrm{II})$ metal ions from industrial wastewater [71]. The maximum adsorption capacity by using WAQI was obtained $9.42 \mathrm{mg} / \mathrm{g}$ by optimized several parameters. In this study, the adsorption is directly proportional to a temperature which shows that reaction is endothermic in nature. The experimental data is well fitted towards the Langmuir isotherm model and obeyed pseudo ksecond-order kinetics. Table 3: shows the maximum adsorption capacities of agricultural waste adsorbents for the remediation of Ni(II) ions.

\begin{tabular}{|c|c|c|c|c|c|}
\hline S.no & Adsorbents & $\begin{array}{l}\text { Adsorption } \\
\text { Capacity (mg/g) }\end{array}$ & $\begin{array}{l}\text { Thermodynamic } \\
\text { Study }\end{array}$ & $\mathrm{pH}$ & References \\
\hline 1. & Barley straw & 35.8 & -- & 4.8 & [68] \\
\hline 2. & $\begin{array}{ll}\text { Hydrochloric } & \text { acid } \\
\text { treated } & \text { rice } \\
\text { bran (HARB) } & \\
\end{array}$ & 149.4 & -- & 6.0 & [69] \\
\hline 3. & $\begin{array}{l}\text { Protonated rice } \\
\text { bran }\end{array}$ & 102.00 & -- & 6.0 & [69] \\
\hline 4. & $\begin{array}{l}\text { Punicagranatum } \\
\text { peel waste }\end{array}$ & 52.0 & Endothermic & 6.0 & [65] \\
\hline 5. & Cashew nut shell & 20 & $\begin{array}{ll}\text { Exothermic and } \\
\text { spontaneous }\end{array}$ & 5.0 & [70] \\
\hline 6. & $\begin{array}{l}\text { Waste acorn of } \\
\text { Quercus } \\
\text { ithaburensis } \\
\text { (WAQI) }\end{array}$ & 9.42 & Endothermic & 5.0 & [71] \\
\hline 7. & $\begin{array}{lr}\text { Citrus } & \text { limettioides } \\
\text { peel } & \text { carbon } \\
(\mathrm{CLPC}) & \end{array}$ & 38.46 & $\begin{array}{l}\text { Spontaneous and } \\
\text { Exothermic }\end{array}$ & 6.0 & [59] \\
\hline
\end{tabular}

Table 3: The maximum adsorption capacities of different agricultural waste adsorbents are shown for the treatment of Ni(II) metal ions.

\subsubsection{Industrial solid wastes}

Industrial solid wastes i.e. fly ash, blast furnace slag, red mud, waste slurry and bio-solids are used as less expensive industrial waste material for the treatment of $\mathrm{Ni}(\mathrm{II})$ from industrial wastewater.

Fly ash is used as an adsorbent generated from thermal power plants where lignite and coal burned for the manufacturing of electricity. The major and important components of fly ash are silica, alumina, iron oxide, calcium oxide and carbon [72]. Globally the fly ash production was 67.5 million tons per year. It may be utilized for the manufacturing of bricks, roads etc. It also comprises of toxic metals, like heavy metals. The maximum adsorption capacity of fly ash for the treatment of nickel ions was $6.48 \mathrm{mg} / \mathrm{g}$ at $\mathrm{pH} 6.0$ [73].

Hannachi et al. studied low-cost adsorbents for the elimination of $\mathrm{Ni}(\mathrm{II})$ ions from aqueous environments [74]. Red mud and Clarified sludge were used for the treatment of nickel ions. The effect of different parameters i.e. $\mathrm{pH}$, temperature, adsorbent nature, initial concentration and contact time was studied. The maximum adsorption capacity of red mud and clarified clay was $13.69 \mathrm{mg} / \mathrm{g}$ and $12.66 \mathrm{mg} / \mathrm{g}$ obtained at the neutral pH. The adsorption process followed the Langmuir isotherm model and the kinetic study was pseudo-second order. Mousavi et al. used nettle ash for the elimination of nickel from aqueous solution [75]. The adsorption capacity of $\mathrm{Ni}(\mathrm{II})$ metal ions was $192.3 \mathrm{mg} / \mathrm{g}$. various parameters were affected in batch adsorption process i.e. $\mathrm{pH}$, temperature, initial concentration and contact time. The data followed the Langmuir isotherm model and the kinetic studies were pseudo-second-order model. Blast furnace slag used for the removal of nickel metal ions and their removal capacity was $55.75 \mathrm{mg} / \mathrm{g}$ at $\mathrm{pH}$ 5.0. The process is well fitted on Freundlich isotherm and it is exothermic in nature. El-Dars et al. utilized blast furnace slag as a sorbent for the treatment of nickel ions and its adsorption capacity was $12.66 \mathrm{mg} / \mathrm{g}$ in $30 \mathrm{~min}$ contact time [76]. Van Hullebusch et al. used anaerobic granular sludge as a low-cost adsorbent for the adsorption of $\mathrm{Ni}(\mathrm{II})$ from industrial wastewater [77]. The adsorption capacity of $\mathrm{Ni}(\mathrm{II})$ ions was $13.3 \mathrm{mg} / \mathrm{g}$ at pH 7.2. The data is well fitted towards the Langmuir isotherm model and followed the pseudo-second-order kinetic model. Table 4: shows the maximum adsorption capacities of industrial waste adsorbents for the remediation of $\mathrm{Ni}(\mathrm{II})$ ions

\begin{tabular}{|c|c|c|c|c|c|}
\hline S.no & Adsorbents & $\begin{array}{l}\text { Adsorption } \\
\text { capacity }(\mathrm{mg} / \mathrm{g})\end{array}$ & $\begin{array}{l}\text { Thermodynamic } \\
\text { Study }\end{array}$ & pH & References \\
\hline 1. & Red mud & 13.69 & Endothermic & 5.0 & [74] \\
\hline 2. & Nettle ash & 192.3 & -- & 6.0 & [75] \\
\hline 3. & $\begin{array}{l}\text { Water cooled blast } \\
\text { furnace slag } \\
\text { (WCBFS) }\end{array}$ & 12.66 & Endothermic & 6.0 & [76] \\
\hline 4. & $\begin{array}{l}\text { Clarified sludge (a } \\
\text { steel } \\
\text { industry waste } \\
\text { material) }\end{array}$ & 14.30 & Endothermic & 5.0 & [74] \\
\hline 5. & $\begin{array}{l}\text { Anaerobic } \\
\text { Granular sludge }\end{array}$ & 13.33 & -- & 7.2 & [77] \\
\hline
\end{tabular}

Table 4: The maximum adsorption capacities of different industrial solid waste adsorbents are shown for the removal of Ni(II) metal ions.

\subsection{Natural Materials}

2.6.1. Clays:-

Clay mineral shows a collection of hydrous alumino-silicates that dominates the clay-sized fraction of soil. Clay mineral used as ion exchangers for the treatment of toxic metals due to their high abundance, low cost and harmless to the surroundings. The crystalline structure of clay was produced by an amalgamation of tetrahedral and octahedral sheets which were further classified into two groups of hydrous phyllosilicates and have the inorganic structural arrangement in 1:1 and 2:1 layer. The structure of the first layer comprises of single tetrahedral coordinated $\left[\mathrm{Si}_{2} \mathrm{O}_{5}\right](\mathrm{OH})_{2}$ layer and that was joined to the edge-shared octahedral $\mathrm{M}(\mathrm{OH})_{6}$ sheet. The clay becomes an excellent adsorbent if it contains a larger surface area, mechanical and chemical stability, high cation exchange capacity and layered structure [78]. Clay minerals are divided into four types of major groups which change in layered structure. The group contains the illite group, the kaolinite group and the smectite group [79].

Kaolins rocks contain four types of minerals such as halloysite, kaolinite, nacrite and dickite. The colour of the kaolinite is white. The chemical composition of kaolinite is $46.3 \%$ silica, $39.8 \%$ alumina and $13.9 \%$ water and it is divided into two layers clay i.e. the layer of tetrahedra attached with alumina octahedral layer through hydroxyl oxygen atoms. Kaolin is the most important and versatile adsorbent and used for the industrial pollutants due to its chemically inert to the range of $\mathrm{pH} 4-9$.

Kaolinite is used as a sorbent for the treatment of nickel metal ions from industrial effluent [80]. The maximum adsorption capacity of nickel metal ion by using kadlinite was $1.669 \mathrm{mg} / \mathrm{g}$. The process followed the Langmuir adsorption model. The thermodynamic and kinetic were also studied i.e. entropy, enthalpy and free energy and these values confirm that the process was endothermic in nature. 
Montmorillonite, saponite, talc, nontronite, and pyrophyllite are some parts of the smectite clay. The chemical characteristics are the major difference between these parts. The structure comprises of silicate layers, sandwiching aluminium hydroxide layer $\left(\mathrm{Al}_{2}(\mathrm{OH})_{4}\right)$. They are utilized as fillers in rubbers, paints, heat and as an electrical.

Ijagbemi et al. studied the efficiency of of-calcined sodium exchanged (Na-MMT) and acid modified montmorillonite (A-MMT) for the treatment of nickel (II) from the aqueous environment [81]. The contact time for both adsorbents was obtained about 230min. The Dubinin-Radushkevich model was well fitted for the treatment of nickel ion onto NaMMT and A-MMT. The adsorption process of both adsorbents was endothermic and spontaneous in nature. The kinetic study of both adsorbents was well fitted for pseudo-second-order chemisorption.

The sorption of nickel metal ions from industrial effluent by using GMZ bentonite at optimized conditions i.e. pH, contact time, ionic strength interference ions and temperature [82]. The process followed the Langmuir adsorption model. The kinetic study studies of this process were pseudo-second order and thermodynamic studies show that it is a spontaneous process and endothermic in nature.

Several clay minerals have been reported i.e. sepiolite silicate clay minerals, Magnetite rich clay, synthetic hydroxyapatite, modified riverbed sand, Clinoptilolite and dolomite powder are successfully utilized for the treatment of nickel metal ions from the water stream.

Katsou et al. used Ultrafiltration membrane with natural aluminosilicate mineral for the elimination of Ni(II) ions from industrial wastewater [83]. The different parameters were examined i.e. $\mathrm{pH}$, temperature, membrane normal pore size and mineral concentration. The adsorption capacity was obtained $25.4 \mathrm{mg} / \mathrm{g}$ at $\mathrm{pH}$ 6.0. The removal efficiency increases with the increase of $\mathrm{pH}$ and temperature. Barati et al. used montmorillonite nano-composites for the treatment of $\mathrm{Cu}(\mathrm{II})$ and $\mathrm{Ni}(\mathrm{II})$ metal ions from an aqueous environment [84]. Various parameters were optimized to obtain maximum adsorption efficiency i.e. $\mathrm{pH}$, temperature, content time and mineral content. The adsorption capacity of $\mathrm{Cu}(\mathrm{II})$ and $\mathrm{Ni}(\mathrm{II}) \mathrm{was}$ found to be 49.26 and $46.0 \mathrm{mg} / \mathrm{g}$ at $\mathrm{pH} 6.0$ and obeyed Langmuir isotherm model. Choksi et al. used clay for the investigation of adsorption studies for the elimination of Ni(II) and Al(III) ions from wastewater [62]. The adsorption capacity of nickel was obtained $97 \mathrm{mg} / \mathrm{g}$ at $\mathrm{pH} 7.5$. This study shows that the $\mathrm{pH}$ and concentration of biomass affect the adsorption kinetics. Landis et al. employed natural bentonite clay to check the adsorption behaviour of Ni(II) from metal finishing wastewater [85]. During the adsorption studies, the different parameters were optimized i.e. $\mathrm{pH}$, temperature, heavy metal concentration and bentonite amount. The adsorption capacity of natural bentonite was $50 \mathrm{mg} / \mathrm{g}$ at $\mathrm{pH}$ 8.0. The data followed the Langmuir isotherm model and the pseudo-second-order kinetic model. The positive value of $\Delta \mathrm{H}$ shows that reaction is endothermic and spontaneous in nature. Liu et al. used sodium mixed bentonite clay for the elimination of Ni(II) metal ions from industrial wastewater under static conditions [86]. Different parameters were optimized i.e. pH, temperature, adsorbent dose and contact time. The equilibrium time of $\mathrm{Ni}(\mathrm{II})$ on Na-bentonite clay was reached up to $200 \mathrm{~min}$. The adsorption capacity of nickel on Na-bentonite clay was $13.96 \mathrm{mg} / \mathrm{g}$ in the $\mathrm{pH}$ range of 6-8. The data followed the Langmuir isotherm model and Pseudo-second order kinetic model. Table 5: shows the maximum adsorption capacities of clay minerals for the remediation of $\mathrm{Ni}(\mathrm{II})$ ions.

\begin{tabular}{|c|c|c|c|c|c|}
\hline S.no & Adsorbents & $\begin{array}{l}\text { Adsorption } \\
\text { Capacity (mg/g) }\end{array}$ & $\begin{array}{l}\text { Thermodynamic } \\
\text { Study }\end{array}$ & pH & References \\
\hline 1. & Vermiculite & 25.4 & Endothermic & 6.0 & [83] \\
\hline 2. & Montmorillonite & 46.0 & -- & 6.0 & [84] \\
\hline 3. & Clay & 97.0 & Endothermic & 7.5 & [62] \\
\hline 4. & Natural bentonite & 50.0 & $\begin{array}{l}\text { Endothermic } \\
\text { Spontaneous }\end{array}$ & 8.0 & [85] \\
\hline 5. & $\begin{array}{l}\text { Sodium mixed } \\
\text { bentonite }\end{array}$ & 13.96 & -- & $6-8$ & [86] \\
\hline
\end{tabular}

Table 5: The maximum adsorption capacities of different Clay minerals adsorbents are shown for the treatment of Ni(II) metal ions.

\subsubsection{Zeolites}

Zeolites are used as highly porous crystalline adsorbent which is made up of alumina-silicates and tetrahedral connected in three-dimensional networks. The pore sizeable takes the molecules up to the size of $1 \mathrm{~nm}$. The structures of Zeolites are usually described with geometry, size and connectivity of pore space. It has the ability to exchange the ions and remediate the toxic heavy metals from industrial wastewater. $0 v e r$ the past 200 years, almost 50 zeolites have been studied but most common are chabazite, Clinoptilolite, heulandite, analcime, phillipsite and erionitemordenite [87].

Clinoptilolite is widely used as abundant and plentiful zeolite, its tabular morphology described the open reticular structure which contains 8-10 membered rings [88]. The exchangeable ions by using this zeolite were $\mathrm{Na}^{+}, \mathrm{K}^{+}, \mathrm{Mg}^{2+}, \mathrm{Ca}^{2+}$ usually occupy these channels. Clinoptilolite zeolite has the ability to remediate a small quantity of toxic metals from the water stream by using the adsorption or ion exchange.

Rajic et al studied on the natural zeolite tuff (clinoptilolite) from the Serbian deposit and used as an adsorbent for the treatment of Ni(II) ions from the aqueous environment [89]. The adsorption capacity was obtained $16.64 \mathrm{mg} / \mathrm{g}$ at the pH 6.0 . The data followed sips isotherm model and obeyed pseudosecond-order kinetics.

Kocaoba et al. studied the utilization of natural clinoptilolite, found from Biga-Canakkale region of Turkey which was used for the treatment of toxic metals from the water stream [90]. The process followed the Langmuir adsorption model. The kinetic studies were also done and obtained pseudo-second order for the treatment of nickel, copper and cadmium. Katsou et al. investigated the utilization of UF membranes which joint with sludge and alumina-silicates minerals, the results indicated the removal efficiency of $80 \%$ nickel ions at pH 6.0 [83]. By using vermiculite mineral highest removal of nickel metal ions was achieved even at high $\mathrm{pH}$. Coruh et al. employed natural zeolite for the remediation of Ni(II) metal ions from aqueous solution by using batch adsorption studies [91]. The effect of several parameters was investigated i.e. $\mathrm{pH}$, temperature, adsorbent dose and initial concentration of metal ions. The adsorption capacity was $8.7 \mathrm{mg} / \mathrm{g}$ at the pH 7.0-8.0 and obeyed Langmuir isotherm model. Sprynskyy et al. carried out the study on the elimination of different heavy metals $\left(\mathrm{Ni}^{2+}, \mathrm{Cu}^{2+}, \mathrm{Pb}^{2+}\right.$ and $\left.\mathrm{Cd}^{2+}\right)$ from single and multicomponent aqueous solution by using pre-treated zeolite [92]. The adsorption consists of three stages i.e. adsorption on the surface of microcrystals, the inversion stage and in the interior part of microcrystal. The finer of zeolite adsorb high amount of metal concentration due to the relative enriching at the proper and higher cleavage plane. The adsorption Capacity of $\mathrm{Ni}^{2+}{ }^{2}$ was obtained $15.5 \mathrm{mg} / \mathrm{g}$ at the $\mathrm{pH}$ 6.2. The data is well fitted towards the Freundlich isotherm model. Hui et al. investigated the removal efficiency and selectivity sequence of mixed metal ions $\left(\mathrm{Co}^{2+}, \mathrm{Cu}^{2+}, \mathrm{Cr}^{3+}, \mathrm{Ni}^{2+}\right.$ and $\left.\mathrm{Zn}^{2+}\right)$ form the aqueous environment by using Zeolite $4 \mathrm{~A}$ [93]. The adsorption capacity of $\mathrm{Ni}^{2+}$ by using $\mathrm{Zeolite} 4 \mathrm{~A}$ was $7.90 \mathrm{mg} / \mathrm{g}$ at $\mathrm{pH}$ 4.0. The adsorption method was affected by several parameters such as $\mathrm{pH}$, temperature, the initial concentration of metal ions, adsorbent dose and contact time. The Ni(II) data followed the pseudo first-order kinetics while the other metal ions followed pseudo second order kinetics. Table 6: shows the maximum adsorption capacities of different natural and synthetically modified zeolite adsorbents are shown for the remediation of Ni(II) metal ions.

\begin{tabular}{llllll}
\hline S.no & Adsorbents & $\begin{array}{l}\text { Adsorption } \\
\text { capacity (mg/g) }\end{array}$ & $\begin{array}{l}\text { Thermodynamic } \\
\text { Study }\end{array}$ & pH & References \\
\hline 1. & Natural zeolitic tuff & 16.64 & $\begin{array}{l}\text { Endothermic } \\
\text { Spontaneous }\end{array}$ & 6.0 & and \\
\hline 2. & Turkish zeolite & 119.0 & -- & 6.0 & $7.0-8.0$ \\
\hline 3. & Natural zeolite & 8.7 & Exothermic & 6.2 & {$[90]$} \\
\hline 4. & $\begin{array}{l}\text { Ukraine } \\
\text { clinoptilolite }\end{array}$ & 15.55 & -- & {$[91]$} \\
\hline 5. & Zeolite 4A & 7.90 & -- & 4.0 & {$[92]$} \\
\hline
\end{tabular}

Table 6: The maximum adsorption capacities $\quad$ of $\quad$ different

synthetically modified zeolite adsorbents are shown for the treatment of $\mathrm{Ni}(\mathrm{II})$ metal ions. 


\subsection{Nanomaterials}

Nanotechnology is the technique of handling the matter at a nano-scale level to generate the devices, particles, structures and systems. At the nano-scale, materials show different physical and chemical properties than their normal sizes [94]. The surface area of the nanoparticle increases by decreasing the particle size. Therefore nanoparticles possess different electrical and magnetic properties as compared to macromolecules [95]. Nanotechnology has established in mostly all branches of sciences. Nanotechnology also deals for the treatment of toxic contaminants i.e. lead, chromium, arsenic, nickel and etc from the aqueous solution. Nano-materials and its effectiveness encouraged us to use these materials for the sorbent for the removal of pollutants from wastewater. Different nano-materials were discovered i.e. nanotubes, nanofibers, nanoparticles, nanowires, dendrimers and nano-sponges [96]. These nanomaterials possess high porosity, small size, active sites for metal rebinding and for the faster remediation of pollutants [97]. The nanostructured materials are famous for strength, stability and green chemistry [98]. In addition, Nano-materials have been employed in different environmental applications i.e. photocatalytic degradation of an organic dye, treatment of contaminated water, contaminant sensing and detection, antibacterial activities etc. [99]. In nanotechnology, Magnetic nanoparticles (MNPs) are mostly used for the treatment of toxic heavy metals from industrial wastewater. Heavy metals i.e. arsenic can be easily adsorbed by using MNPs and it is a cheap to process for the water treatment [100]. Carbon nanotubes (CNTs) are also employed for the removal of organic pollutants, inorganic pollutants and dyes [94]. So with an increase in the enhancement and effectiveness of nanoscience, the nanomaterials are used in low-cost filters, active and energetic membranes, control of membrane of polluting and its usage for industrial wastewater.

Kandah et al. manufactured Multi-walled carbon nanotubes (MWCNTs) by chemical decomposition as the utilization of acetylene gas in the existence of Ferrocene catalyst at $800^{\circ} \mathrm{C}$ and by adding conc. Nitric acid will be oxidized at $150^{\circ} \mathrm{C}$ [101]. Authors investigated both (as- oxidized and produced) CNTs for the remediation of $\mathrm{Ni}(\mathrm{II})$ metal ions. The maximum sorption capacities by using both CNTs were $18.083 \mathrm{mg} / \mathrm{g}$ and $49.261 \mathrm{mg} / \mathrm{g}$. The process is well fitted Langmuir adsorption model.

Lu et al. investigated the removal of nickel ions by oxidized with sodium hypochlorite single and multi-walled carbon nanotubes (SWCNTs \& MWCNTs) [102]. They observed the surface properties of carbon nano-tubes became more effectively after oxidation, and hydrophilic in nature and increase the adsorption of nickel metal ions.

Alibadi et al. prepared nanofiber membranes by using the electrospinning method which possesses unique properties i.e. high porosity and larger surface area. These properties are appropriate for the inorganic metals from industrial effluent [103]. Adolph et al. prepared triphenylphosphine-linked multiwalled carbon nanotubes (Tpp-MWCNTs) and purified MWCNTs for the adsorption of Ni(II) ion from the aqueous system and their adsorption capabilities were compared [104]. The removal efficiency was increased with an increase of $\mathrm{pH}$ of both adsorbents. The maximum adsorption capacity of triphenylphosphine-linked multiwalled carbon nanotubes (Tpp-MWCNTs) and purified MWCNTs was observed 100mg/g and 55.55mg/g at the pH 6.0. The data is well fitted to the Langmuir isotherm model and obeyed pseudo-second-order kinetic model. Ren, et al. synthesise $\delta$ - $\mathrm{MnO}_{2}$ particles and $\mathrm{Graphene}$ nano-sheet (GNS) for the removal of Ni(II) by using microwave-assisted method [105]. The adsorption efficiency of Ni(II) was affected by the various parameters i.e. $\mathrm{pH}$, the initial concentration of metal ion, temperature and time. In this study, the adsorption isotherm, kinetic and thermodynamic parameters were also carried out. The data was well fitted towards Langmuir isotherm and obeyed pseudo-second-order kinetics. The adsorption capacity of $\delta-\mathrm{MnO}_{2}$ was $30.63 \mathrm{mg} / \mathrm{g}$ and graphene nano-sheet was $3.00 \mathrm{mg} / \mathrm{g}$. The positive value of $\Delta \mathrm{H}$ and $\Delta \mathrm{S}$ suggest that reaction is endothermic in nature and increase in randomness during the adsorption of $\mathrm{Ni}(\mathrm{II})$ ions. The negative values of $\Delta \mathrm{G}$ show that reaction is spontaneous in nature. Figure 6: shows the diagram of different adsorbents for the removal of $\mathrm{Ni}(\mathrm{II})$ ions and Table 7: shows maximum adsorption capacities of different nanoparticle adsorbents are shown for the removal of $\mathrm{Ni}(\mathrm{II})$ metal ions.

\section{Adsorption}

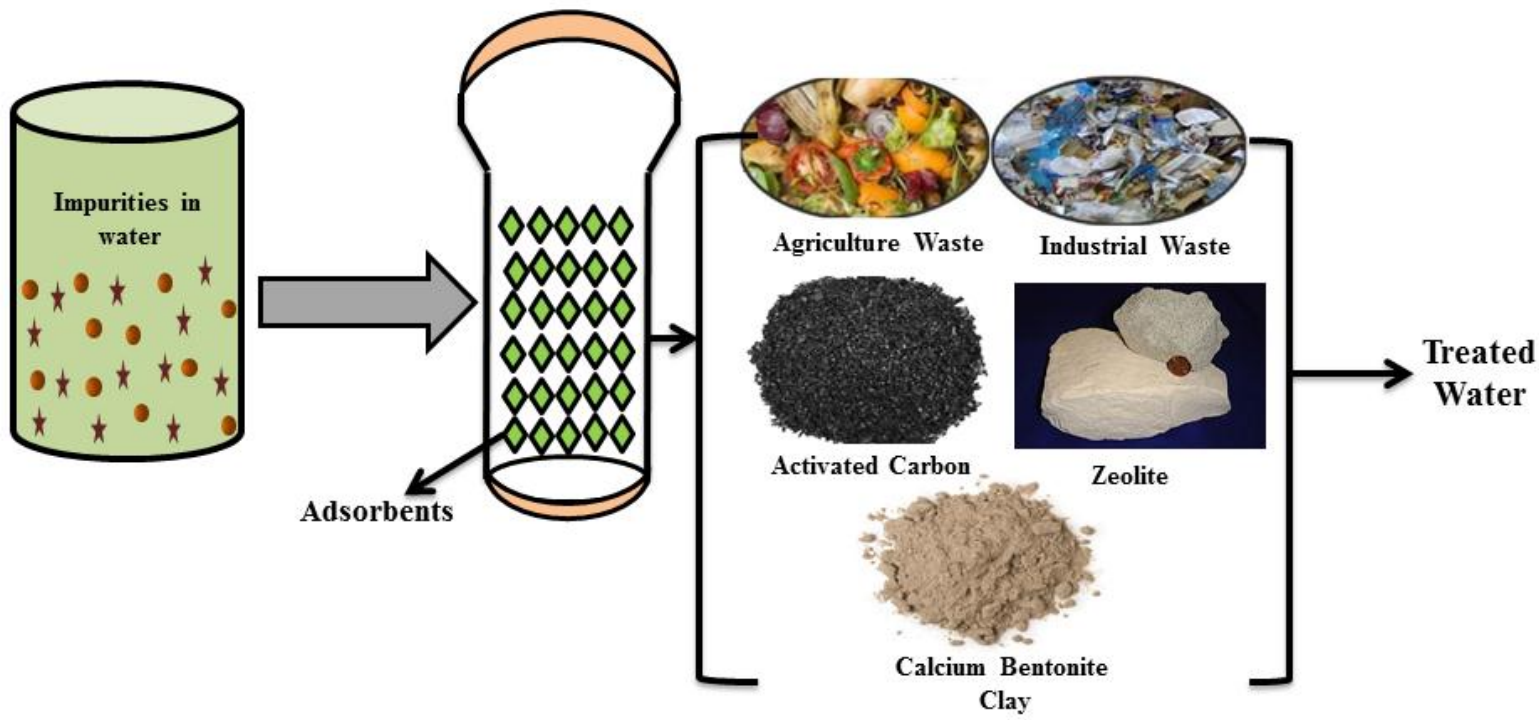

Adsorbents for water treatment

Figure 6: Diagram of Adsorption method for the remediation of Ni(II) metal ions from aqueous solution.

\begin{tabular}{llllll}
\hline S.no. & Adsorbents & $\begin{array}{l}\text { Adsorption } \\
\text { Capacity (mg/g) }\end{array}$ & $\begin{array}{l}\text { Thermodynamic } \\
\text { Study }\end{array}$ & $\mathbf{p H}$ & References \\
\hline 1. & 100.00 & -- & 6.0 & {$[104]$} \\
& $\begin{array}{l}\text { Synthesized } \\
\text { triphenylphosphine- } \\
\text { linked multiwalled } \\
\text { carbon nanotubes } \\
\text { [TPP-MWCNTs] }\end{array}$ & & & & \\
& Purified MWCNTs & 55.55 & -- & 6.0 & {$[104]$} \\
\hline 2. & & & & \\
\hline
\end{tabular}




\begin{tabular}{llllll}
\hline & & & & \\
\hline 3. & $\rho-M n 02$ & 30.63 & Endothermic & 8.0 & {$[105]$} \\
\hline 4. & $\begin{array}{l}\text { Graphene nanosheet } \\
\text { (GNS) }\end{array}$ & 3.00 & Endothermic & 8.0 & {$[105]$} \\
\hline 5. & $\begin{array}{l}\text { Multi-walled carbon } \\
\text { nanotubes } \\
\text { (MWCNTs) }\end{array}$ & 49.2 & -- & 6.0 & {$[101]$} \\
\hline
\end{tabular}

Table 7: The maximum adsorption capacities of different nanoparticle adsorbents are shown for the treatment of Ni(II) metal ions.

\section{Advantages}

$>$ In adsorption, mostly adsorbents are efficient and effective.

They are low cost and can be used for household and community. Limitations

They have high adsorption capacity and require low energy consumption.

$>$ Adsorption is highly affected by several types of the interferences i.e. sulphates, phosphates, nitrates etc.

$>$ The adsorption capacity of adsorbents varies by changing the $\mathrm{pH}$ of the solution.

$>$ At some extent, it is a time-consuming method.

\subsection{Electrochemical Treatment}

In the last few decades, electrochemical treatment technologies are used for the remediation of Ni(II) ions from wastewater [106]. Koene et al. concise the electrochemical techniques used for the remediation of nickel from industrial effluent [107]. In the following summary the main focus on electrocoagulation, electro-dialysis method.

Electrocoagulation comprises of the formation of coagulants by usable electrodes [108]. In this method, aluminium and iron anodes are liquefied by applying a potential to them, whereas hydroxyl ions and hydrogen gas are prepared by water electrolysis process at the cathode surface. Aluminium and iron will nearly directly become polymeric hydroxides and they are used as coagulating agents. In aluminium case, the inorganic metals are remediating from the solution by various processes: direct reduction at cathode electrode, co-precipitation with aluminium hydroxide and hydroxides formation at the cathode by hydroxyl ions [109]. Kabdas, li et al. eliminated the nickel and zinc ions from the water stream by using electrocoagulation techniques with stainless electrodes [110]. In this process, $\mathrm{Zn}$ and Ni were separated through hydroxide precipitation and combination in colloidal material prepared by the creation of $\mathrm{Fe}(\mathrm{OH})_{3}$ ions.

Akbal et al. investigated the elimination of copper, chromium and nickel from metal plating wastewater with iron and aluminium electrodes [111]. The effect of $\mathrm{pH}$, current density, electrode material and conductance of removal efficiency was also studied. The results show that electrocoagulation with Fe$\mathrm{Al}$ electrode pair was very efficient and effective and the removal efficiency was able to achieve $100 \% \mathrm{Cu}, 100 \% \mathrm{Cr}$ and $100 \% \mathrm{Ni}$ at $20 \mathrm{~min}$ time, $\mathrm{pH}$ was 3.0 and the current density was $10 \mathrm{~mA} / \mathrm{Cm}^{2}$. Umran et al. studied the elimination of $\mathrm{Cd}, \mathrm{Cu}$ and Ni heavy metals by electrocoagulation from industrial wastewater [112]. It was observed that the removal efficiencies were affected by $\mathrm{pH}$ and applied current density. The removal efficiencies were obtained for $\mathrm{Cd}, \mathrm{Cu}$ and $\mathrm{Ni}$ was $99.78 \%, 98.90 \%$ and $99.98 \%$ at the current density of $30 \mathrm{~mA} / \mathrm{cm}^{2}$ and at pH 7. Mansour et al. employed electrocoagulation technique for the treatment Nickel from drinking water [113]. During the coagulation process, Aluminium ions are emerged from the electrodes and react with Ni(II) ions in drinking water which forming precipitates. Various parameters affected the electrocoagulation process i.e. applied density, pH and initial concentration. The removal efficiency of Nickel ions was in the range of 88.60-99.5\%. Subramanian et al. used the electrocoagulation process for the simultaneous elimination of heavy metals i.e. mercury, lead and nickel from the polluted water [114]. In this study adsorption isotherm, thermodynamics parameters and kinetic studies were carried out. The results showed that the maximum removal efficiency of heavy metals was obtained at $\mathrm{pH} 7.0$ and the current density was $0.15 \mathrm{~A} / \mathrm{dm}^{2}$. The data is well fitted to Langmuir isotherm and obeyed second order kinetics. The temperature studies show that the process is endothermic and spontaneous in nature.

Electro-flotation is a removal process which produced tiny bubbles of hydrogen and oxygen gases emerged from water electrolysis to float the contaminants at the surface of effluent. The electro-flotation process can be used with the combination of aluminium electrocoagulation. This process was employed for the remediation of $\mathrm{Ni}$ (II) from the polymetallic solution. The removal efficiency was obtained $99 \%$ at the $\mathrm{pH}$ of 8.0 [115].

Electro-deionization is the combination of ion exchange and electrodialysis. Dermentzis et al. employed an electro-deionization method for the removal of nickel from electroplating rinse water [116]. The removal efficiency was obtained $100 \%$ at pH 4.0 by using platinum graphite powder platinum as an anode and platinum platinized titanium platinum as a cathode. The initial concentration of nickel was $0.1 \mathrm{mg} / \mathrm{L}$ at the flow rate of $2.02 \mathrm{x} 10^{-4}$ and the current density was $30 \mathrm{~A} / \mathrm{m}^{2}$.

Electro-dialysis is separation method where ions are shifted over ion exchange resin with the help of electricity between two electrodes. Tzanetakis et al. investigate the removal of Cobalt and Nickel from their sulphate solution by using two cation exchange and an anion exchange membrane, a stainless steel cathode and platinum oxide based coated titanium cobalt, a suitable complexing agent is EDTA [117]. Figure 7: shows the diagram of the electrocoagulation technique for the removal of $\mathrm{Ni}(\mathrm{II})$ ions and Table 8: shows the different electrochemical techniques for the removal of Ni(II) ions. 


\section{Electrocoagulation}

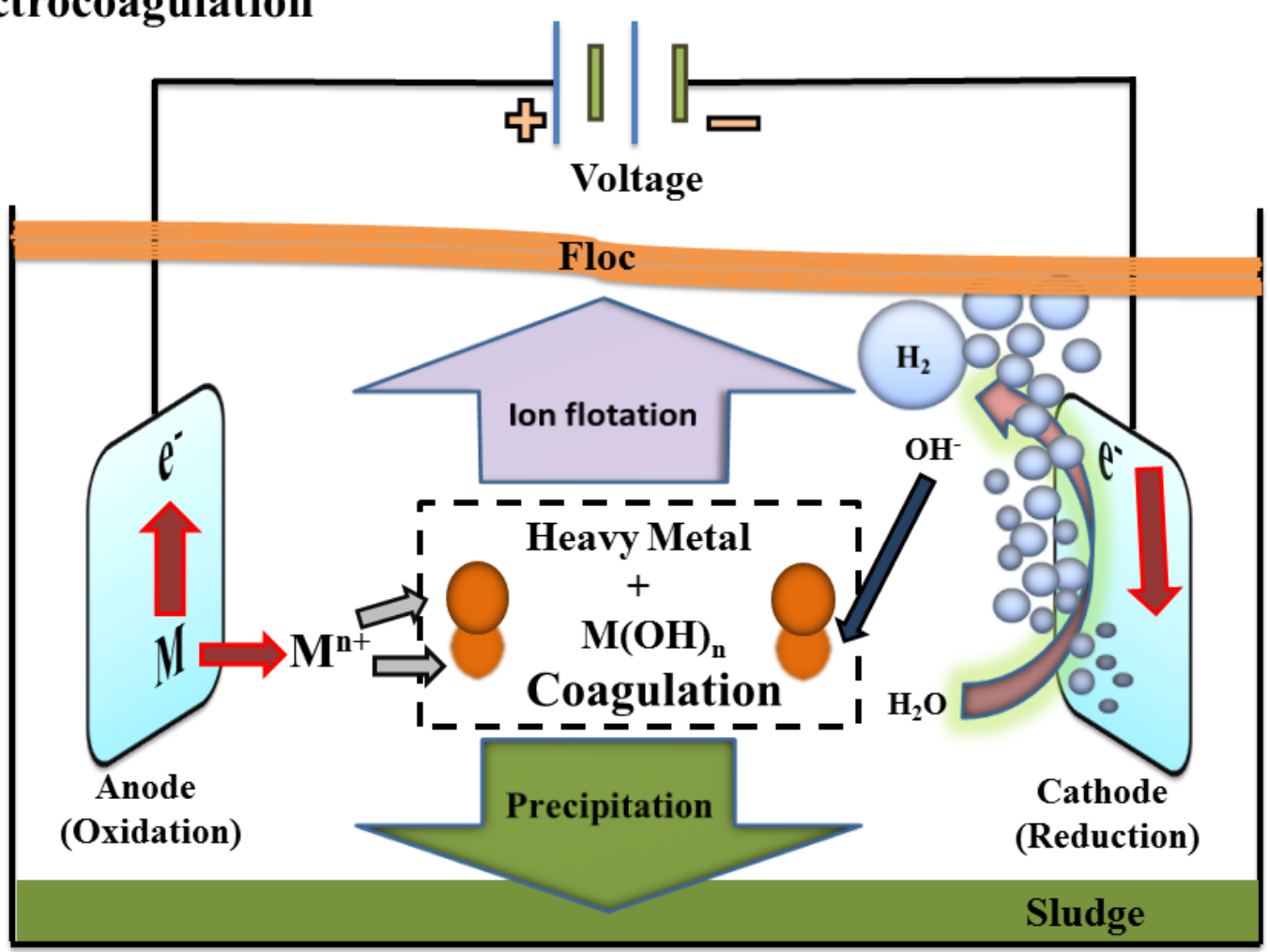

Figure 7: Diagram of Electrocoagulation technique for the remediation of Ni(II) from aqueous solution

\begin{tabular}{|c|c|c|c|c|c|c|}
\hline S.no & Technique & Cathode & Anode & $\begin{array}{l}\text { Removal } \\
\text { Efficiency \% }\end{array}$ & pH & References \\
\hline 1. & Electroflotation & Aluminium & Aluminium & 99 & 8.0 & {$[115]$} \\
\hline 2. & Electrocoagulation & $\begin{array}{l}\text { Aluminium } \\
\text { Stainless Steel }\end{array}$ & $\begin{array}{l}\text { Aluminium } \\
\text { Stainless Steel }\end{array}$ & -- & $4.5-7.5$ & [109] \\
\hline 3. & Electrodeionization & $\begin{array}{l}\text { Platinum } \\
\text { Platinized } \\
\text { titanium } \\
\text { Platinum }\end{array}$ & $\begin{array}{l}\text { Platinum } \\
\text { Graphite } \\
\text { powder } \\
\text { Platinum }\end{array}$ & 100 & 4.0 & [116] \\
\hline 4. & Electrodialysis & $\begin{array}{l}\text { Pt oxide coated } \\
\text { Ti }\end{array}$ & Stainless steel & 69 & -- & [117] \\
\hline
\end{tabular}

Table 8: List of the electrochemical technologies used for the treatment of Ni(II) ions
Advantages
$>\quad$ This is an effective technique for the removal of soluble and insoluble dyes.
$>\quad$ It breaks down all the toxic compounds present in the cell.
$>\quad$ Not affected by salt present in the wastewater.
Limitations
$>\quad$ It can produce a large amount of sludge and cause secondary pollution.
$>\quad$ It consumes a large amount of electricity.
The efficiency of the technique depends upon the nature of the solution.

3.

Water contamination by toxic metals is a worldwide environmental problem due to bioaccumulation in nature. To improve more environmental conditions, several treatment techniques are employed i.e. membrane filtration, chemical precipitation, ion exchange, ion flotation, adsorption and electrochemical techniques for the elimination of toxic ions from aqueous system. It is concluded from the literature that after adsorption, ion exchange technique is prominently used for the extraction of toxic metals.

Adsorption is an effective and economically process which is used for the removal of toxic metal ions. This review article shows several types of adsorbents use for the treatment of $\mathrm{Ni}$ (II) ions from aqueous media. The high cost of activated carbon limited its used for the treatment of Ni(II) ions. However, several types of agricultural, industrial, natural and biosorbents have been used as an efficient adsorbent for the treatment of Ni(II) ions.

Many low-cost adsorbents are modified for the adsorption of Ni(II) ions to increase its adsorption efficiency but still to know the adsorption mechanism, very less has been carried out. Thus, there is good research scope in this direction.

Acknowledgement

This work was supported and funded by Pakistan Science Foundation, Pakistan under research grant number PSF/Res/S-SU/Chem (465).

\section{References}

[1] C. Santhosh, V. Velmurugan, G. Jacob, S. K. Jeong, A. N. Grace, and A. Bhatnagar, "Role of nanomaterials in water treatment applications: a review," Chemical Engineering Journal, vol. 306, pp. 1116-1137, 2016.

[2] W. U. J. W. Supply and S. M. Programme, Progress on drinking water and sanitation: 2014 Update: World Health Organization, 2014.

[3] M. M. A. Shirazi, A. Kargari, and M. J. A. Shirazi, "Direct contact membrane distillation for seawater desalination," Desalination and Water Treatment, vol. 49, pp. 368-375, 2012.

[4] H. S. Rai, M. S. Bhattacharyya, J. Singh, T. Bansal, P. Vats, and U. Banerjee, "Removal of dyes from the effluent of textile and dyestuff manufacturing 
industry: a review of emerging techniques with reference to biological treatment," Critical reviews in environmental science and technology, vol. 35, pp. 219-238, 2005.

[5] X. Du, H. Zhang, X. Hao, G. Guan, and A. Abudula, "Facile preparation of ion-imprinted composite film for selective electrochemical removal of nickel (II) ions," ACS applied materials \& interfaces, vol. 6, pp. 9543-9549, 2014.

[6] O. Sadeghi, N. Tavassoli, M. Amini, H. Ebrahimzadeh, and N. Daei, "Pyridine-functionalized mesoporous silica as an adsorbent material for the determination of nickel and lead in vegetables grown in close proximity by electrothermal atomic adsorption spectroscopy," Food Chemistry, vol. 127, pp. 364-368, 2011.

[7] R. Sharma and B. Singh, "Removal of Ni (II) ions from aqueous solutions using modified rice straw in a fixed bed column," Bioresource technology, vol. 146 , pp. $519-524,2013$

[8] K. Lascelles, L. Morgan, D. Nicholls, and D. Beyersmann, "Nickel compounds, Ullmann's Encyclopedia of Industrial Chemistry," ed: Wiley-VCH Verlag GmbH \& Co. KGaA, 2005

[9] E. Denkhaus and K. Salnikow, "Nickel essentiality, toxicity, and carcinogenicity," Critical reviews in oncology/hematology, vol. 42, pp. 35-56, 2002.

[10] M. Vieira, A. A. Neto, M. Gimenes, and M. Da Silva, "Sorption kinetics and equilibrium for the removal of nickel ions from aqueous phase on calcined Bofe bentonite clay," Journal of Hazardous Materials, vol. 177, pp. 362-371, 2010

[11] X. Zhang and X. Wang, "Adsorption and desorption of nickel (II) ions from aqueous solution by a lignocellulose/montmorillonite nanocomposite," PloS one, vol. 10, p. e0117077, 2015.

[12] R. G. Garrett, "Natural sources of metals to the environment," Human and Ecological Risk Assessment, vol. 6, pp. 945-963, 2000.

[13] K. K. Das and V. Büchner, "Effect of nickel exposure on peripheral tissues: role of oxidative stress in toxicity and possible protection by ascorbic acid," Reviews on environmental health, vol. 22, pp. 157-173, 2007.

[14] F. Fu and Q. Wang, "Removal of heavy metal ions from wastewaters: a review," Journal of environmental management, vol. 92, pp. 407-418, 2011.

[15] D. Zamboulis, E. N. Peleka, N. K. Lazaridis, and K. A. Matis, "Metal ion separation and recovery from environmental sources using various flotation and sorption techniques," Journal of Chemical Technology and Biotechnology, vol. 86, pp. 335-344, 2011.

[16] V. Coman, B. Robotin, and P. Ilea, "Nickel recovery/removal from industrial wastes: A review," Resources, Conservation and Recycling, vol. 73, pp. 229-238, 2013.

[17] S. R. Dhokpande, J. P. Kaware, and S. J. Kulkarni, "Research for removal of nickel from waste water-A Review," International Journal of Science, Engineering and Technology Research, vol. 2, pp. 2162-2166, 2013.

[18] A. Kaur and S. Sharma, "Removal of heavy metals from waste water by using various adsorbents-A review," Indian Journal of Science and Technology, vol. 10, 2017.

[19] Y. Ku and I.-L. Jung, "Photocatalytic reduction of Cr (VI) in aqueous solutions by UV irradiation with the presence of titanium dioxide," Water research, vol. 35, pp. 135-142, 2001.

[20] M. A. Hashim, S. Mukhopadhyay, J. N. Sahu, and B. Sengupta, "Remediation technologies for heavy metal contaminated groundwater," Journal of environmental management, vol. 92, pp. 2355-2388, 2011

[21] A. Özverdi and M. Erdem, "Cu2+, Cd2+ and Pb2+ adsorption from aqueous solutions by pyrite and synthetic iron sulphide," Journal of hazardous materials, vol. 137, pp. 626-632, 2006.

[22] I. Giannopoulou and D. Panias, "Copper and nickel recovery from acidic polymetallic aqueous solutions," Minerals engineering, vol. 20, pp. 753$760,2007$.

[23] C. Sist and G. P. Demopoulos, "Nickel hydroxide precipitation from aqueous sulfate media," JOM Journal of the Minerals, Metals and Materials Society, vol. 55, pp. 42-46, 2003.

[24] G. Escudero, E. Espinoza, and F. Rao, "Chemical Precipitation of Nickel Species from Waste Water," International Research Journal of Pure and Applied Chemistry, vol. 15, p. 1, 2017.

[25] K. Tanong, L.-H. Tran, G. Mercier, and J.-F. Blais, "Recovery of Zn (II), Mn (II), Cd (II) and Ni (II) from the unsorted spent batteries using solvent extraction, electrodeposition and precipitation methods," Journal of cleaner production, vol. 148, pp. 233-244, 2017.

[26] T. Subbaiah, S. Mallick, K. Mishra, K. Sanjay, and R. Das, "Electrochemical precipitation of nickel hydroxide," Journal of power sources, vol. 112, pp. 562-569, 2002.

[27] A. Dąbrowski, Z. Hubicki, P. Podkościelny, and E. Robens, "Selective removal of the heavy metal ions from waters and industrial wastewaters by ion-exchange method," Chemosphere, vol. 56, pp. 91-106, 2004.

[28] T. A. Kurniawan, G. Y. Chan, W.-H. Lo, and S. Babel, "Physico-chemical treatment techniques for wastewater laden with heavy metals," Chemical engineering journal, vol. 118, pp. 83-98, 2006.

[29] F. Gode and E. Pehlivan, "Removal of chromium (III) from aqueous solutions using Lewatit S 100: the effect of pH, time, metal concentration and temperature," Journal of Hazardous Materials, vol. 136, pp. 330-337, 2006.

[30] A. Azimi, A. Azari, M. Rezakazemi, and M. Ansarpour, "Removal of heavy metals from industrial wastewaters: a review," ChemBioEng Reviews, vol. 4, pp. 37-59, 2017.

[31] B. Alyüz and S. Veli, "Kinetics and equilibrium studies for the removal of nickel and zinc from aqueous solutions by ion exchange resins," Journal of Hazardous Materials, vol. 167, pp. 482-488, 2009.

[32] P. S. Kumar, K. Ramakrishnan, and R. Gayathri, "Removal of nickel (II) from aqueous solutions by ceralite IR 120 cationic exchange resins," J. Eng. Sci. Technol, vol. 5, pp. 232-243, 2010.

[33] R. Dave, G. Dave, and V. Mishra, "REMOVAL OF NICKEL FROM ELETROPLATING WASTEWATER BY WEAKLY BASIC CHELATING ANION EXCHANGE RESINS: DOWEX 50x4, DOWEX 50x2 AND DOWEX M-4195," Journal of Applied Sciences in Environmental Sanitation, vol. 6, 2011.

[34] T. Zewail and N. Yousef, "Kinetic study of heavy metal ions removal by ion exchange in batch conical air spouted bed," Alexandria Engineering Journal, vol. 54, pp. 83-90, 2015.

[35] E. N. Peleka, G. P. Gallios, and K. A. Matis, "A perspective on flotation: a review," Journal of Chemical Technology \& Biotechnology, vol. 93, pp. 615623, 2018.

[36] F. S. Hoseinian, B. Rezai, E. Kowsari, and M. Safari, "Kinetic study of Ni (II) removal using ion flotation: Effect of chemical interactions," Minerals Engineering, vol. 119, pp. 212-221, 2018.

[37] F. M. Doyle and Z. Liu, "The effect of triethylenetetraamine (Trien) on the ion flotation of Cu 2+ and Ni 2+," Journal of colloid and interface science, vol. 258, pp. 396-403, 2003

[38] Z. Liu and F. M. Doyle, "Ion flotation of Co2+, Ni2+, and Cu2+ using dodecyldiethylenetriamine (Ddien)," Langmuir, vol. 25, pp. 8927-8934, 2009.

[39] A. Turtureanu, C. Georgescu, and L. Oprean, "Nickel removal from aqueous solutions by flotation with cationic collector. Determination of the optimum separation conditions," relation, vol. 100, p. 1, 2008.

[40] F. S. Hoseinian, M. Irannajad, and A. J. Nooshabadi, "Ion flotation for removal of Ni (II) and Zn (II) ions from wastewaters," International Journal of Mineral Processing, vol. 143, pp. 131-137, 2015.

[41] M. Barakat, "New trends in removing heavy metals from industrial wastewater," Arabian Journal of Chemistry, vol. 4, pp. 361-377, 2011.

[42] D. S. Patil, S. M. Chavan, and J. U. K. Oubagaranadin, "A review of technologies for manganese removal from wastewaters," Journal of Environmental Chemical Engineering, vol. 4, pp. 468-487, 2016.

[43] M. Mohsen-Nia, P. Montazeri, and H. Modarress, "Removal of $\mathrm{Cu} 2+$ and Ni2+ from wastewater with a chelating agent and reverse osmosis processes," Desalination, vol. 217, pp. 276-281, 2007.

[44] U. Ipek, "Removal of Ni (II) and Zn (II) from an aqueous solutionby reverse osmosis," Desalination, vol. 174, pp. 161-169, 2005.

[45] J. Landaburu-Aguirre, E. Pongrácz, A. Sarpola, and R. L. Keiski, "Simultaneous removal of heavy metals from phosphorous rich real wastewaters by micellar-enhanced ultrafiltration," Separation and purification technology, vol. 88, pp. 130-137, 2012.

[46] G. Borbély and E. Nagy, "Removal of zinc and nickel ions by complexation-membrane filtration process from industrial wastewater," Desalination, vol. 240, pp. 218-226, 2009.

[47] A. Kryvoruchko, L. Yurlova, and B. Kornilovich, "Purification of water containing heavy metals by chelating-enhanced ultrafiltration," 
Desalination, vol. 144, pp. 243-248, 2002.

[48] Z. Murthy and L. B. Chaudhari, "Application of nanofiltration for the rejection of nickel ions from aqueous solutions and estimation of membrane transport parameters," Journal of Hazardous Materials, vol. 160, pp. 70-77, 2008.

[49] Z. Murthy and L. B. Chaudhari, "Rejection behavior of nickel ions from synthetic wastewater containing Na2SO4, NiSO4, MgCl2 and CaCl2 salts by nanofiltration and characterization of the membrane," Desalination, vol. 247, pp. 610-622, 2009.

[50] L. Yurlova, A. Kryvoruchko, and B. Kornilovich, "Removal of Ni (II) ions from wastewater by micellar-enhanced ultrafiltration," Desalination, vol 144, pp. 255-260, 2002.

[51] R. Molinari, T. Poerio, and P. Argurio, "Selective separation of copper (II) and nickel (II) from aqueous media using the complexationultrafiltration process," Chemosphere, vol. 70, pp. 341-348, 2008.

[52] J.-J. Qin, M.-N. Wai, M.-H. Oo, and F.-S. Wong, "A feasibility study on the treatment and recycling of a wastewater from metal plating," Journal of Membrane Science, vol. 208, pp. 213-221, 2002.

[53] A. W. Mohammad, R. Othaman, and N. Hilal, "Potential use of nanofiltration membranes in treatment of industrial wastewater from Ni-P electroless plating," Desalination, vol. 168, pp. 241-252, 2004.

[54] K. A. Krishnan, K. Sreejalekshmi, and R. Baiju, "Nickel (II) adsorption onto biomass based activated carbon obtained from sugarcane bagasse pith," Bioresource technology, vol. 102, pp. 10239-10247, 2011.

[55] V. Gupta, "Application of low-cost adsorbents for dye removal-A review," Journal of environmental management, vol. 90, pp. 2313-2342, 2009.

[56] M. Zhou and L. Lei, "Electrochemical regeneration of activated carbon loaded with p-nitrophenol in a fluidized electrochemical reactor," Electrochimica acta, vol. 51, pp. 4489-4496, 2006.

[57] E. Pehlivan and G. Arslan, "Removal of metal ions using lignite in aqueous solution-Low cost biosorbents," Fuel processing technology, vol. 88, pp. 99-106, 2007.

[58] A. Ewecharoen, P. Thiravetyan, E. Wendel, and H. Bertagnolli, "Nickel adsorption by sodium polyacrylate-grafted activated carbon," Journal of Hazardous Materials, vol. 171, pp. 335-339, 2009.

[59] R. Sudha, K. Srinivasan, and P. Premkumar, "Removal of nickel (II) from aqueous solution using Citrus Limettioides peel and seed carbon," Ecotoxicology and environmental safety, vol. 117, pp. 115-123, 2015.

[60] A. Keränen, T. Leiviskä, A. Salakka, and J. Tanskanen, "Removal of nickel and vanadium from ammoniacal industrial wastewater by ion exchange and adsorption on activated carbon," Desalination and Water Treatment, vol. 53, pp. 2645-2654, 2015.

[61] K. Kadirvelu, K. Thamaraiselvi, and C. Namasivayam, "Adsorption of nickel (II) from aqueous solution onto activated carbon prepared from coirpith," Separation and purification technology, vol. 24, pp. 497-505, 2001.

[62] P. M. Choksi and V. Y. Joshi, "Adsorption kinetic study for the removal of nickel (II) and aluminum (III) from an aqueous solution by natural adsorbents," Desalination, vol. 208, pp. 216-231, 2007.

[63] G. Wang, A. Li, and M. Li, "Sorption of nickel ions from aqueous solutions using activated carbon derived from walnut shell waste," Desalination and Water Treatment, vol. 16, pp. 282-289, 2010.

[64] M. Betancur, P. Bonelli, J. Velásquez, and A. Cukierman, "Potentiality of lignin from the Kraft pulping process for removal of trace nickel from wastewater: effect of demineralisation," Bioresource technology, vol. 100, pp. 1130-1137, 2009.

[65] A. Bhatnagar and A. Minocha, "Biosorption optimization of nickel removal from water using Punica granatum peel waste," Colloids and Surfaces B: Biointerfaces, vol. 76, pp. 544-548, 2010.

[66] G. Crini, "Non-conventional low-cost adsorbents for dye removal: a review," Bioresource technology, vol. 97, pp. 1061-1085, 2006.

[67] A. Ewecharoen, P. Thiravetyan, and W. Nakbanpote, "Comparison of nickel adsorption from electroplating rinse water by coir pith and modified coir pith," Chemical engineering journal, vol. 137, pp. 181-188, 2008.

[68] A. Thevannan, R. Mungroo, and C. H. Niu, "Biosorption of nickel with barley straw," Bioresource technology, vol. 101, pp. 1776-1780, 2010.

[69] M. N. Zafar, I. Aslam, R. Nadeem, S. Munir, U. A. Rana, and S. U.-D. Khan, "Characterization of chemically modified biosorbents from rice bran for biosorption of Ni (II)," Journal of the Taiwan Institute of Chemical Engineers, vol. 46, pp. 82-88, 2015.

[70] P. S. Kumar, S. Ramalingam, S. D. Kirupha, A. Murugesan, T. Vidhyadevi, and S. Sivanesan, "Adsorption behavior of nickel (II) onto cashew nut shell: Equilibrium, thermodynamics, kinetics, mechanism and process design," Chemical Engineering Journal, vol. 167, pp. 122-131, 2011.

[71] E. Malkoc and Y. Nuhoglu, "Nickel (II) adsorption mechanism from aqueous solution by a new adsorbent-Waste acorn of Quercus ithaburensis," Environmental Progress \& Sustainable Energy, vol. 29, pp. 297-306, 2010.

[72] B. Bayat, "Comparative study of adsorption properties of Turkish fly ashes: I. The case of nickel (II), copper (II) and zinc (II)," Journal of Hazardous Materials, vol. 95, pp. 251-273, 2002.

[73] V. C. Srivastava, I. D. Mall, and I. M. Mishra, "Equilibrium modelling of single and binary adsorption of cadmium and nickel onto bagasse fly ash," Chemical engineering journal, vol. 117, pp. 79-91, 2006.

[74] Y. Hannachi, N. A. Shapovalov, and A. Hannachi, "Adsorption of nickel from aqueous solution by the use of low-cost adsorbents," Korean journal of chemical engineering, vol. 27, pp. 152-158, 2010.

[75] H. Z. Mousavi and S. Seyedi, "Nettle ash as a low cost adsorbent for the removal of nickel and cadmium from wastewater," International Journal of Environmental Science \& Technology, vol. 8, pp. 195-202, 2011.

[76] F. M. El-Dars, M. A. Elngar, S. T. Abdel-Rahim, N. El-Hussiny, and M. Shalabi, "Kinetic of nickel (II) removal from aqueous solution using different particle size of water-cooled blast furnace slag," Desalination and Water Treatment, vol. 54, pp. 769-778, 2015.

[77] E. D. van Hullebusch, A. Peerbolte, M. H. Zandvoort, and P. N. Lens, "Sorption of cobalt and nickel on anaerobic granular slu dges: isotherms and sequential extraction," Chemosphere, vol. 58, pp. 493-505, 2005.

[78] M. G. da Fonseca, M. M. de Oliveira, and L. N. Arakaki, "Removal of cadmium, zinc, manganese and chromium cations from aqueous solution by a clay mineral," Journal of Hazardous Materials, vol. 137, pp. 288-292, 2006.

[79] F. Uddin, "Clays, nanoclays, and montmorillonite minerals," Metallurgical and Materials Transactions A, vol. 39, pp. $2804-2814,2008$.

[80] Ö. Yavuz, Y. Altunkaynak, and F. Güzel, "Removal of copper, nickel, cobalt and manganese from aqueous solution by kaolinite," Water research, vol. 37, pp. 948-952, 2003.

[81] C. O. Ijagbemi, M.-H. Baek, and D.-S. Kim, "Adsorptive performance of un-calcined sodium exchanged and acid modified montmorillonite for Ni 2+ removal: Equilibrium, kinetics, thermodynamics and regeneration studies," Journal of Hazardous Materials, vol. 174, pp. 746-755, 2010.

[82] S. Yang, J. Li, Y. Lu, Y. Chen, and X. Wang, "Sorption of Ni (II) on GMZ bentonite: effects of pH, ionic strength, foreign ions, humic acid and temperature," Applied Radiation and Isotopes, vol. 67, pp. 1600-1608, 2009.

[83] E. Katsou, S. Malamis, K. J. Haralambous, and M. Loizidou, "Use of ultrafiltration membranes and aluminosilicate minerals for nickel removal from industrial wastewater," Journal of Membrane Science, vol. 360, pp. 234-249, 2010.

[84] A. Barati, M. Asgari, T. Miri, and Z. Eskandari, "Removal and recovery of copper and nickel ions from aqueous solution by poly (methacrylamideco-acrylic acid)/montmorillonite nanocomposites," Environmental Science and Pollution Research, vol. 20, pp. 6242-6255, 2013.

[85] N. Alandis, O. Aldayel, W. Mekhemer, J. Hefne, and H. Jokhab, "Thermodynamic and kinetic studies for the adsorption of Fe (III) and Ni (II) ions from aqueous solution using natural bentonite," Journal of dispersion science and technology, vol. 31, pp. 1526-1534, 2010.

[86] Z.-r. Liu and S.-q. Zhou, "Adsorption of copper and nickel on Na-bentonite," Process safety and environmental protection, vol. 88, pp. 62-66, 2010.

[87] C. Martínez and J. Pérez-Pariente, "Zeolites and ordered porous solids," in 3rd FEZA School on Zeolites: fundamentals and applications", ed: Editorial Universitat Politecnica de Valencia Valencia, 2011.

[88] M. Panayotova and B. Velikov, "Influence of zeolite transformation in a homoionic form on the removal of some heavy metal ions from wastewater," Journal of Environmental Science and Health, Part A, vol. 38, pp. 545-554, 2003.

[89] N. Rajic, D. Stojakovic, M. Jovanovic, N. Z. Logar, M. Mazaj, and V. Kaucic, "Removal of nickel (II) ions from aqueous solutions using the natural clinoptilolite and preparation of nano-NiO on the exhausted clinoptilolite," Applied Surface Science, vol. 257, pp. 1524-1532, 2010.

[90] S. Kocaoba, Y. Orhan, and T. Akyüz, "Kinetics and equilibrium studies of heavy metal ions removalby use of natural zeolite," Desalination, vol. 214 , pp. 1-10, 2007.

[91] S. Çoruh and O. N. Ergun, "Ni2+ removal from aqueous solutions using conditioned clinoptilolites: Kinetic and isotherm studies," Environmental 
Progress \& Sustainable Energy: An Official Publication of the American Institute of Chemical Engineers, vol. 28, pp. 162-172, 2009.

[92] M. Sprynskyy, B. Buszewski, A. P. Terzyk, and J. Namieśnik, "Study of the selection mechanism of heavy metal (Pb2+, Cu2+, Ni2+, and Cd2+) adsorption on clinoptilolite," Journal of colloid and interface science, vol. 304, pp. 21-28, 2006.

[93] K. Hui, C. Y. H. Chao, and S. Kot, "Removal of mixed heavy metal ions in wastewater by zeolite 4A and residual products from recycled coal fly ash," Journal of Hazardous Materials, vol. 127, pp. 89-101, 2005.

[94] S. Kumar, W. Ahlawat, G. Bhanjana, S. Heydarifard, M. M. Nazhad, and N. Dilbaghi, "Nanotechnology-based water treatment strategies," Journal of nanoscience and nanotechnology, vol. 14, pp. 1838-1858, 2014.

[95] S. Yang, J. Li, D. Shao, J. Hu, and X. Wang, "Adsorption of Ni (II) on oxidized multi-walled carbon nanotubes: effect of contact time, pH, foreign ions and PAA," Journal of Hazardous Materials, vol. 166, pp. 109-116, 2009.

[96] D. Schmidt, D. Shah, and E. P. Giannelis, "New advances in polymer/layered silicate nanocomposites," Current Opinion in Solid State and Materials Science, vol. 6, pp. 205-212, 2002.

[97] T. A. Kurniawan, M. E. Sillanpää, and M. Sillanpää, "Nanoadsorbents for remediation of aquatic environment: local and practical solutions for global water pollution problems," Critical reviews in environmental science and technology, vol. 42, pp. 1233-1295, 2012.

[98] B. Bhushan, Springer handbook of nanotechnology: Springer Science \& Business Media, 2010.

[99] I. Ali, "New generation adsorbents for water treatment," Chemical reviews, vol. 112, pp. 5073-5091, 2012.

[100] M. M. Doroodmand, Z. Tahvildar, and M. H. Sheikhi, "Multi-Walled Carbon Nanotubes/Polyacrylonitrile Composite as Novel Semi-Permeable Filter for Water Treatment Process," Science of Advanced Materials, vol. 4, pp. 1085-1095, 2012.

[101] M. I. Kandah and J.-L. Meunier, "Removal of nickel ions from water by multi-walled carbon nanotubes," Journal of Hazardous Materials, vol. 146, pp. 283-288, 2007.

[102] C. Lu and C. Liu, "Removal of nickel (II) from aqueous solution by carbon nanotubes," Journal of Chemical Technology and Biotechnology, vol. 81, pp. 1932-1940, 2006.

[103] M. Aliabadi, M. Irani, J. Ismaeili, H. Piri, and M. J. Parnian, "Electrospun nanofiber membrane of PEO/Chitosan for the adsorption of nickel, cadmium, lead and copper ions from aqueous solution," Chemical engineering journal, vol. 220, pp. 237-243, 2013.

[104] M. A. Adolph, Y. M. Xavier, P. Kriveshini, and K. Rui, "Phosphine functionalised multiwalled carbon nanotubes: A new adsorbent for the removal of nickel from aqueous solution," Journal of Environmental Sciences, vol. 24, pp. 1133-1141, 2012.

[105] Y. Ren, N. Yan, Q. Wen, Z. Fan, T. Wei, M. Zhang, and J. Ma, "Graphene/ $\delta$-MnO2 composite as adsorbent for the removal of nickel ions from wastewater," Chemical Engineering Journal, vol. 175, pp. 1-7, 2011.

[106] G. Chen, "Electrochemical technologies in wastewater treatment," Separation and purification technology, vol. 38, pp. 11-41, 2004.

[107] L. Koene and L. Janssen, "Removal of nickel from industrial process liquids," Electrochimica acta, vol. 47, pp. 695-703, 2001.

[108] M. Y. Mollah, P. Morkovsky, J. A. Gomes, M. Kesmez, J. Parga, and D. L. Cocke, "Fundamentals, present and future perspectives of electrocoagulation," Journal of Hazardous Materials, vol. 114, pp. 199-210, 2004.

[109] I. Heidmann and W. Calmano, "Removal of Zn (II), Cu (II), Ni (II), Ag (I) and Cr (VI) present in aqueous solutions by aluminium electrocoagulation," Journal of Hazardous Materials, vol. 152, pp. 934-941, 2008.

[110] I. Kabdaşll, T. Arslan, T. Ölmez-Hancı, I. Arslan-Alaton, and O. Tünay, "Complexing agent and heavy metal removals from metal plating effluent by electrocoagulation with stainless steel electrodes," Journal of Hazardous Materials, vol. 165, pp. 838-845, 2009.

[111] F. Akbal and S. Camcl, "Copper, chromium and nickel removal from metal plating wastewater by electrocoagulation," Desalination, vol. 269, pp. 214-222, 2011.

[112] U. T. Un and S. E. Ocal, "Removal of heavy metals (Cd, Cu, Ni) by electrocoagulation," International Journal of Environmental Science and Development, vol. 6, p. 425, 2015.

[113] T. U. A. Current, "Removal of nickel from drinking water by electrocoagulation technique using alternating current," Current Research in Chemistry, vol. 4, pp. 41-50, 2012.

[114] S. Vasudevan, J. Lakshmi, and G. Sozhan, "Optimization of electrocoagulation process for the simultaneous removal of mercury, lead, and nickel from contaminated water," Environmental Science and Pollution Research, vol. 19, pp. 2734-2744, 2012.

[115] M. Belkacem, M. Khodir, and S. Abdelkrim, "Treatment characteristics of textile wastewater and removal of heavy metals using the electroflotation technique," Desalination, vol. 228, pp. 245-254, 2008.

[116] K. Dermentzis, "Removal of nickel from electroplating rinse waters using electrostatic shielding electrodialysis/electrodeionization," Journal of Hazardous Materials, vol. 173, pp. 647-652, 2010.

[117] N. Tzanetakis, W. Taama, K. Scott, R. Jachuck, R. Slade, and J. Varcoe, "Comparative performance of ion exchange membranes for electrodialysis of nickel and cobalt," Separation and Purification Technology, vol. 30, pp. 113-127, 2003. 